\title{
QUALITY OF WISCONSIN STORMWATER, 1989-94
}

By Roger T. Bannerman, Andrew D. Legg, and Steven R. Greb

U.S. GEOLOGICAL SURVEY

Open-File Report 96-458

Prepared in cooperation with the WISCONSIN DEPARTMENT OF NATURAL RESOURCES

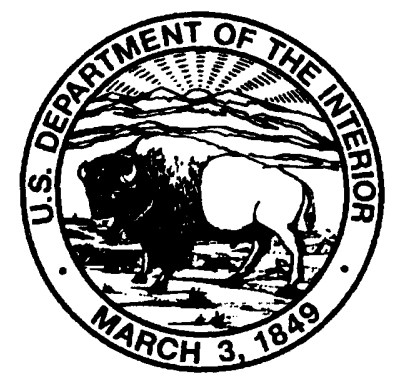




\title{
U.S. DEPARTMENT OF THE INTERIOR BRUCE BABBITT, Secretary
}

\author{
U.S. GEOLOGICAL SURVEY \\ Gordon P. Eaton, Director
}

District Chief

U.S. Geological Survey

6417 Normandy Lane

Madison, WI 53719
U.S. Geological Survey

Branch of Information Services

Box 25286

Denver, CO 80225-0286 


\section{CONTENTS}

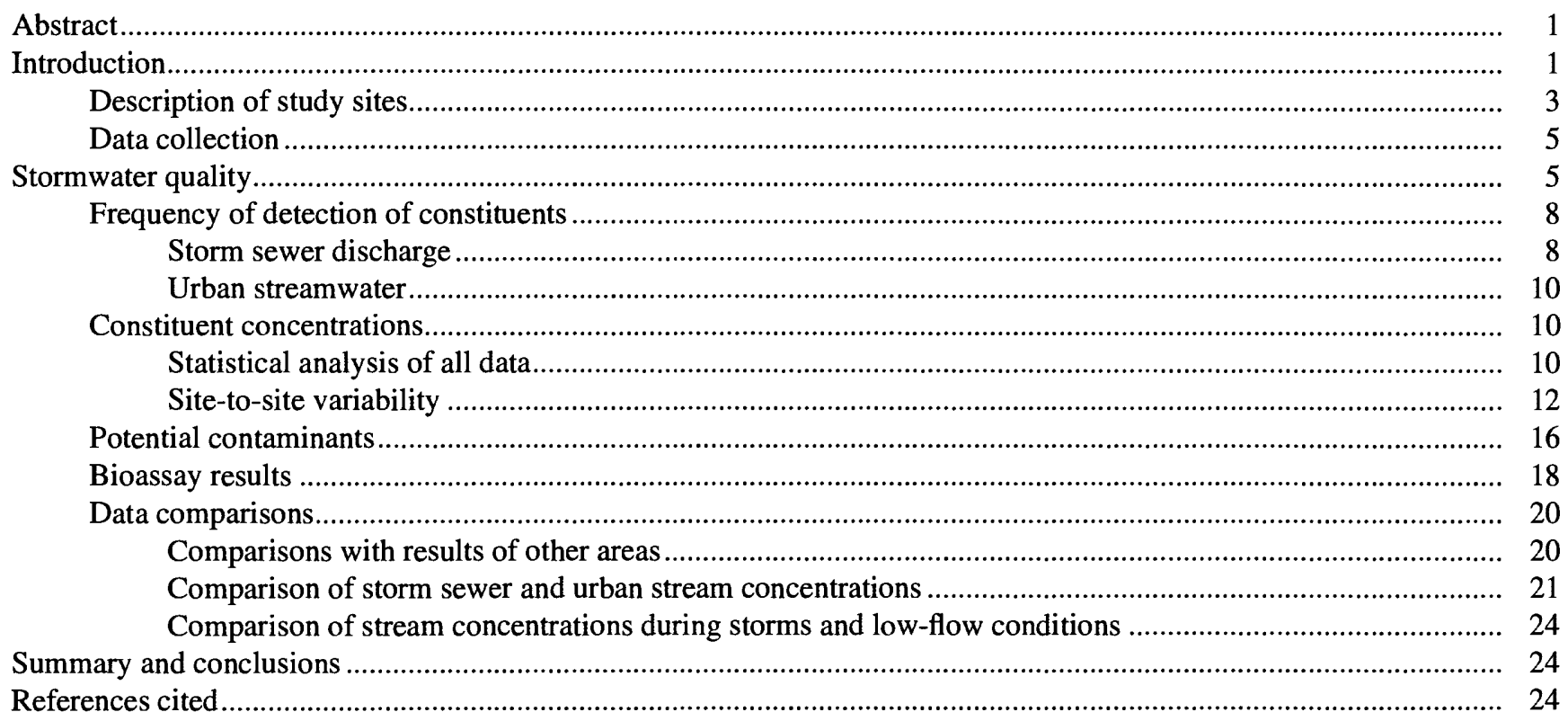

\section{FIGURES}

1. Differences in concentrations of selected constituents of urban stormwater in Wisconsin, by land use

2. Differences in concentrations of selected constituents in storm-sewer discharge and urban streamwater in Wisconsin

3. Boxplots of selected constituents during low-flow and high-flow periods at Lincoln Creek in Milwaukee, Wisconsin.

\section{TABLES}

1. Urban stormwater-monitoring study sites among four projects in Wisconsin

2. Percentages of land use in drainage areas above urban storm-sewer and stream sites in Wisconsin.

3. Description of land uses for storm-sewer-monitoring sites in Wisconsin

4. Constituents analyzed in stormwater from storm sewers and urban streams in Wisconsin

5. Frequency of occurrence for constituents detected above minimum reporting limits in at least 10 percent of the Wisconsin storm sewer stormwater samples....

6. Frequency of occurrence for constituents detected above minimum reporting limits in at least 10 percent of the Wisconsin urban stream stormwater samples.

7. Summary statistics for event mean concentrations of constituents with detection frequencies of at least 10 percent at Wisconsin storm-sewer-monitoring sites.

8. Summary statistics for event mean concentrations of constituents with detection frequencies of at least 10 percent in four urban Wisconsin streams.

9. Probability of event mean concentration of constituents in Wisconsin stormwater exceeding Wisconsin surface-water- and ground-water-quality standards

10. Comparison of event mean concentrations of selected constituents in Wisconsin storm-sewer samples with those in storm-sewer samples from other states with those in storm-sewer samples from other states.... 


\begin{tabular}{rll}
\hline Multiply & By & To Obtain \\
\hline inch (in.) & & millimeter \\
mile (mi) & 25.4 & kilometer \\
foot (ft) & 1.609 & meter \\
acre & 0.3048 & square kilometer \\
square mile $\left(\mathrm{mi}^{2}\right)$ & $4.047 \times 10^{-3}$ & square kilometer \\
gallon per minute & 2.590 & cubic foot per day \\
cubic foot per month $\left(\mathrm{ft}^{3} / \mathrm{mo}\right)$ & 192.5 & cubic meter per month
\end{tabular}

Temperature, in degrees Fahrenheit $\left({ }^{\circ} \mathrm{F}\right)$ can be converted to degrees Celsius $\left({ }^{\circ} \mathrm{C}\right)$ by use of the following equation:

$$
{ }^{\circ} \mathrm{C}=5 / 9\left({ }^{\circ} \mathrm{F}-32\right) \text {. }
$$

Abbreviated water-quality units: Chemical concentrations and water temperature are given in metric units. Chemical concentration is given in milligrams per liter $(\mathrm{mg} / \mathrm{L})$ or micrograms per liter $(\mu \mathrm{g} / \mathrm{L})$. Milligrams per liter is a unit expressing the concentration of chemical constituents in solution as weight (milligrams) of solute per unit volume (liter) of water. One thousand micrograms per liter is equivalent to one milligram per liter. For concentrations less than $7,000 \mathrm{mg} / \mathrm{L}$, the numerical value is the same as for concentrations in parts per million. 


\title{
Quality of Wisconsin Stormwater, 1989-94
}

\author{
By Roger T. Bannerman ${ }^{1}$, Andrew D. Legg ${ }^{2}$, and Steven R. Greb ${ }^{1}$
}

\section{Abstract}

Water-quality data were compiled from four urban stormwater monitoring projects conducted in Wisconsin between 1989 and 1994. These projects included monitoring in both storm-sewer pipes and urban streams. A total of 147 constituents were analyzed for in stormwater sampled from 10 storm-sewer pipes and four urban streams. Land uses represented by the storm-sewer watersheds included residential, commercial, industrial, and mixed. For about one-half the constituents, at least 10 percent of the event mean concentrations exceeded the laboratory's minimum reporting limit. Detection frequencies were greater than 75 percent for many of the heavy metals and polycyclic aromatic hydrocarbons in both the storm sewer and stream samples, whereas detection frequencies were about 20 percent or greater for many of the pesticides in both types of samples. Stormwater concentrations for conventional constituents, such as suspended solids, chloride, total phosphorus, and fecal coliform bacteria were greater than minimum reporting limits almost 100 percent of the time.

Concentrations of many of the constituents were high enough to say that stormwater in the storm sewers and urban streams might be contributing to the degradation of the streams. In this report, constituents defined as potential contaminants are those for which the laboratory minimum report limit was exceeded for at least 10 percent of the sampled storm events, and for which at least one event mean concentration exceeded an established water-quality standard. Storm-sewer samples had event mean concentrations of lead, copper, zinc, cadmium, and silver that frequently exceeded Wisconsin's acute toxicity criteria for cold water fisheries. Wisconsin's human cancer criteria was exceeded almost 100 percent of the time for polycyclic aromatic hydrocarbons in stormwater samples from storm sewers and streams. Maximum concentrations of diazinon found in storm sewers exceeded recommended levels of diazinon. Storm-sewer samples also exceeded Wisconsin's ground-water enforcement standards for pesticides, PCB's, phthalates, and chloride. Defined by criteria in this report, potential contaminants included five metals (lead, zinc, copper, silver, and cadmium), nine polycyclic aromatic hydrocarbons, Bis(2-ethylhexyl)phthalate, four pesticides (DDT, atrazine, alachlor, and 2,4D), suspended solids, chlorides, total phosphorus, BOD 5-day, and bacteria.

Wisconsin stormwater quality was similar to stormwater quality monitored in other states. Nearly one-half of median concentrations of constituents in Wisconsin stormwater were within 30 percent of the medians from other states. The closest agreement was seen for biochemical oxygen demand, total phosphorus, and total recoverable zinc. Similarities in stormwater quality for the storm sewer and urban streams indicated the storm sewers were a major source of water to the streams during storm events. Concentrations of potential contaminants in urban streams increased dramatically during storm events as compared to baseflow concentrations.

\section{INTRODUCTION}

Many of Wisconsin's urban streams are highly degraded (Masterson and Bannerman, 1994; Simonson and Lyons, 1993). Fish populations and species diversity have been greatly reduced in these streams, and the quality of most of the streams makes them unsuitable for recreational uses. In the 1940's, brown trout could be caught in the Menomonee River in Milwaukee; in the 1990's, urban reaches of the river support virtually no sport fisheries (Jones, 1991; Lizhu and others, 1995). These findings are similar to findings in studies

\footnotetext{
${ }^{1}$ Wisconsin Department of Natural Resources, Madison, Wis. ${ }^{2}$ U.S. Geological Survey, Madison, Wis.
} 
of urban streams in other parts of the country (Pitt and others, 1995). Strong relations have been identified between the degree of urbanization in a watershed and the extent of damage to the biological community in a stream (Booth and Jackson, 1994; Schueler, 1994). These relations suggest that urbanization is a major reason why many Wisconsin streams are currently degraded and why more streams could be degraded in the future.

Urban runoff can adversely affect aquatic systems by altering a stream's normal flow regime, destroying fish habitat, and degrading water quality (Horner and others, 1994). Urban runoff subjects streams not only to higher flows during storm events, but also to substantially reduced flows in between storms. Higher flow can impair stream habitat by eroding streambanks and scouring the streambed, while decreased flows in the streams between storms makes the habitat unsuitable for many aquatic animals. Sediment is a conventional constituent that not only buries important habitat but also impairs important functions of aquatic life, such as feeding. Potentially toxic constituents, such as metals and polycyclic aromatic hydrocarbons, could sufficiently stress aquatic life to eliminate one or more species from the stream. Temperature increases in the stream can also stress aquatic life (Horner and others, 1994). Habitat destruction and long-term exposure to potentially toxic constituents have been cited as the two principal factors in the degradation of urban streams (Field and Pitt, 1990; Gustav and others, 1994). Investigators studying the effects of stormwater disagree, however, about the relative importance of each factor, especially the importance of water quality in general, and individual potentially toxic constituents in particular (Lee and Lee-Jones, 1994; Pitt and others, 1995).

Previous studies have found many types of conventional and potentially toxic constituents in urban runoff (U.S. Environmental Protection Agency, 1983; Fram and others, 1987). Of special interest are the many types of potentially toxic constituents found in stormwater monitored around the country. Concentrations of the more frequently detected constituents have been used to evaluate relative importance of these constituents to the quality of a stream. In the absence of water-quality standards specifically developed for stormwater, most stormwater-monitoring projects have referred to surface-water-quality criteria for toxic substances to identify which potentially toxic constituents could be a problem. Results from the Nationwide
Urban Runoff Program (NURP) for example, indicated that concentrations of some metals, such as zinc and copper, regularly exceeded surface-water-quality criteria for toxic substances, whereas the concentrations of some organic constituents occasionally exceeded the criteria (U.S. Environmental Protection Agency, 1983).

Wisconsin's efforts to control the effects of urbanization on water quality are being managed through several programs, including the Wisconsin Nonpoint Source Program and the Wisconsin Pollutant Discharge Elimination System (NPDES) Stormwater Regulatory Program. These programs are intended to protect receiving water from negative effects of future development and to reduce the harmful effects of urban runoff in existing urban areas. Understanding as much as possible about the effects of urban runoff is important to the successful implementation of these programs. Even without a complete knowledge of the effects of the individual constituents, however, any information about which constituents are most likely to degrade the receiving waters, especially potentially toxic constituents, can be used to improve the chances of making sound management decisions.

Tailoring the best management practices (BMP's) to the factors most responsible for the problems in a stream will greatly increase the cost effectiveness of efforts to implement stormwater-management programs. With the projected cost of BMP installation exceeding $\$ 30$ million for some streams, the question of how well the money is used becomes even more important.

The purpose of this report is to describe the quality of urban stormwater in Wisconsin between 1989 and 1994. This description includes a summary of event mean concentrations ${ }^{3}$ and an evaluation of the significance of the observed concentrations to the health of a receiving water. Summary statistics, such as medians, were determined for all those constituents for which at least 10 percent of their event mean concentrations exceeded the laboratory minimum reporting values. The most important part of the evaluation was identifying a list of potential contaminants in Wisconsin stormwater. A potential contaminant is defined as any constituent whose concentration exceeded the minimum reporting value for a least 10 percent of the storm

\footnotetext{
${ }^{3}$ Event mean concentration is defined as the total constituent load divided by the total runoff volume of stormwater (U.S. Environmental Protection Agency, 1983).
} 
Table 1. Urban stormwater-monitoring study sites among four projects in Wisconsin

[Numbers in parentheses are standard industrial classification codes]

\begin{tabular}{clc}
\hline $\begin{array}{c}\text { Project } \\
\text { number }\end{array}$ & \multicolumn{1}{c}{ Study-site name } & Number of samples collected \\
\hline 1 & \multicolumn{1}{c}{ Urban Toxics Project (1989-90) } \\
\hline & Monroe Street & 13 \\
& Hastings Street & 9 \\
& Wood Center & 19 \\
& Noyes Creek & 9 \\
& Underwood Creek & 13 \\
\hline 2 & Nonpoint Source Evaluation Monitoring Project (1992-94) \\
\hline \multirow{3}{*}{ Monroe Street } & 63 \\
& Syene Road & 92 \\
& Lincoln Creek & 33 \\
& Menominee River & 61 \\
\hline 3 & Easy to Use Method for Industrial Monitoring Project (1993-94) \\
\hline \multirow{3}{*}{ A (3714) } & 6 \\
& B (2821) & 6 \\
& C (3561) & 6 \\
& D (4215) & 6 \\
\hline 4 & Lake Superior Demonstration Project (1993-94) \\
\hline & Third Street & 12 \\
& Tower Avenue & 12 \\
\hline
\end{tabular}

events and which had a concentration, for at least one storm event, that exceeded an established water-quality standard. Both surface-water and ground-water-quality standards were used to identify potential contaminants. Other parts of the evaluation included comparing median concentrations found in Wisconsin stormwater with values measured in other states, comparing constituent concentrations in low flow and in stormwater in urban streams, presenting available stormwater bioassay results, and comparing constituent concentrations in storm sewers and urban streams.

The report lists event mean concentrations measured as part of four separate stormwater monitoring projects in urban areas around Wisconsin. Although each project had a unique purpose, the sample collection techniques were the same for all the projects and the same two laboratories were used to analyze most of the samples. All the projects were done by the U.S. Geological Survey (USGS), in cooperation with Wisconsin Department of Natural Resources. The consistent approach to all the projects provided a unique opportunity to create a large data base for describing the quality of Wisconsin stormwater. The projects were completed between September 1989 and August 1994. A total of 14 sites were monitored; stormwater samples were collected at the outfalls of 10 storm sewers and from four urban streams.

\section{Description of Study Sites}

A total of 14 monitoring sites are included in this report (table 1). Thirteen of the study sites were in Wisconsin, and one was in Marquette, Mich. (table 2). Nine of the Wisconsin sites were in the Milwaukee metropolitan area, three were in Madison, and the remaining site was in the city of Superior. At 10 sites, water-quality samples were collected from storm-sewer outfalls. Samples from the four remaining sites were collected from urban streams. Stream study sites ranged from 1,325 to 76,898 acres. The storm-sewer study sites were relatively small, ranging from only 1.4 to 288.3 acres.

Most of the common urban land use types were present in the storm-sewer study sites. Three of the storm-sewer sites (Monroe Street, Wood Center, and 

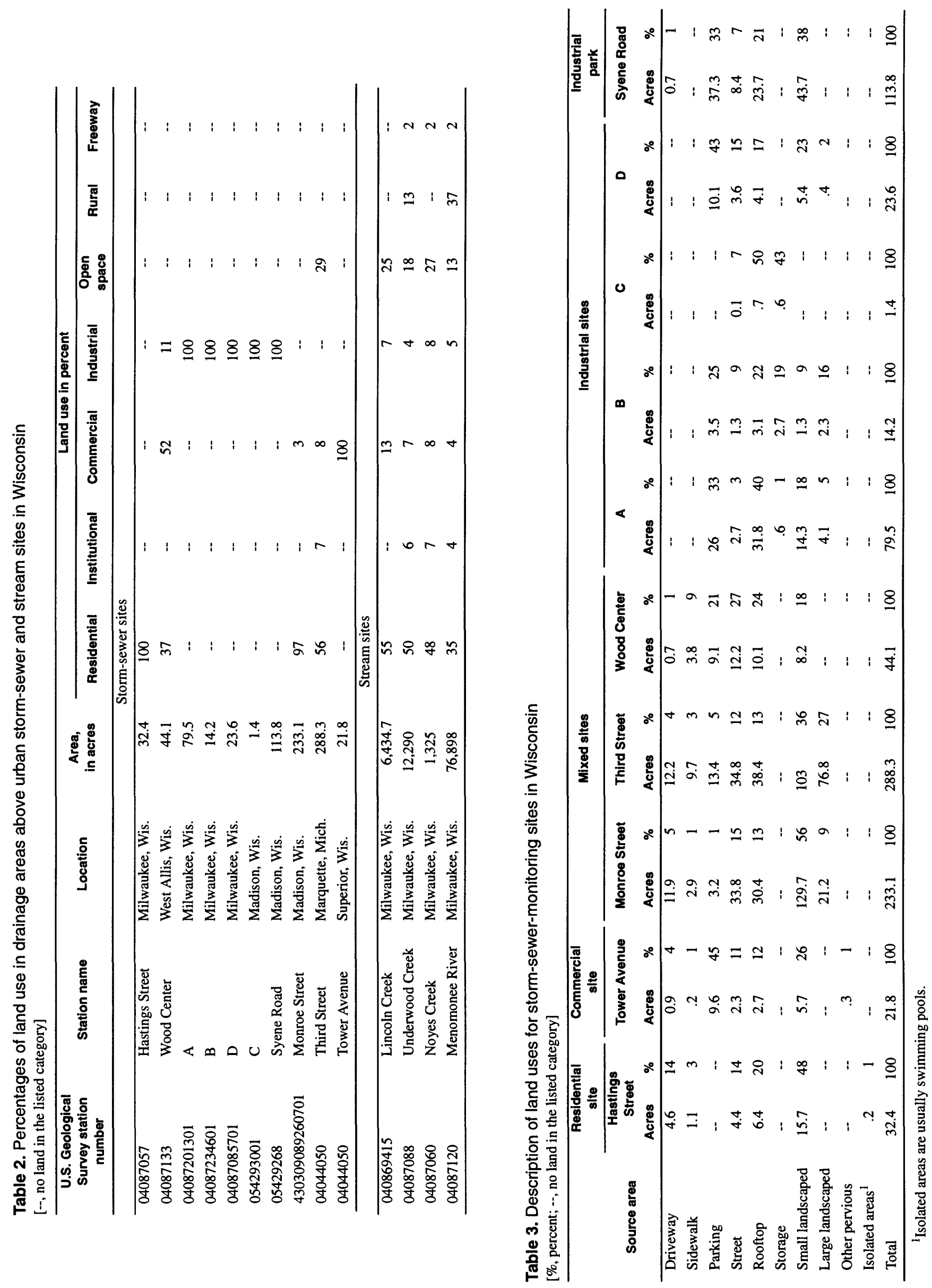
Third Street) had mixed land-use types. Seven of the storm-sewer sites represented a single land-use type; four were light-industrial sites (A,B,C,\&D), one was a commercial site (Tower Avenue), one was a residential site (Hastings Street), and one was an industrial park (Syene Road). Most of the land in the stream study sites is entirely urbanized, ranging from 100 percent for the Lincoln Creek and Noyes Creek sites to 63 percent for the Menomonee River site.

Acreage of each type of urban surface, such as rooftops and streets, was digitized and entered into a geographic information system data base (table 3). Other information, such as percentage of impervious area, is also available for most of the study sites (Bannerman and others, 1993; Bannerman and others, 1983; J.J. Steuer, USGS, written commun., 1995). Land-use designations reflect differences in the percentage of each source site. For example, residential sites had a larger percentage of lawns than commercial sites. The features that distinguished the industrial sites from the industrial park were that each industrial site represented a single industry and did not include any city streets. The "streets" in the industrial sites were not traditional streets but were distinguished from other paved areas on the basis of where most of the truck traffic was concentrated.

All the study sites were in the northern temperate climate zone. Annual average precipitation for the northern temperature climate zone was 31.8 in. for water years $1961-90^{4}$. (This amount includes approximately 40 to $100 \mathrm{in}$. of snowfall annually.) The average temperature was $43^{\circ} \mathrm{F}$ for the period $1895-1990$. The ground is generally frozen from mid-December until early April (Pamela Naber-Knox, Wisconsin State Climatologist, oral commun., 1995).

\section{Data Collection}

All urban water-quality data compiled in this report were collected by the USGS. The reported value for each sample represents the event mean concentration of a storm. An approximation of the event mean concentration was calculated using flow-weighted composite samples for each storm. As predetermined

\footnotetext{
${ }^{4}$ Water year in U.S. Geological Survey reports is the 12 month period, October 1 through September 30. The water year is designated by the calendar year in which it ends and which includes 9 of the 12 months. Thus, the year ending September 30 , 1990 , is called the " 1990 water year."
}

runoff volumes are exceeded during a storm, automated samplers collect discrete samples that are composited for analysis as an event mean concentration (Bannerman and others, 1993). For the Urban Toxics Project and the Nonpoint Source Evaluation Monitoring Project, stormwater runoff was sampled yearround.

The integrity of the sample-collection methods was ensured by quality-assurance/quality-control procedures described in detail by Corsi and others (1995). These procedures were followed with satisfactory consistency throughout the projects.

Samples collected at urban runoff monitoring sites were analyzed at either the Wisconsin State Laboratory of Hygiene or the U.S. Geological Survey National Water Quality Laboratory in Arvada, Colo. U.S. Environmental Protection Agency (USEPA) accredited methods were followed for sample analysis, although these methods and corresponding analytical detection limits have been adjusted through the years.

A different constituent list was selected for each stormwater project. Altogether the projects analyzed a total of 147 constituents (table 4). Samples for both the Nonpoint Source Evaluation Monitoring and Lake Superior Demonstration Projects were analyzed for all but one of the conventional constituents, while a much shorter list was selected for the other two projects. The USEPA Priority Pollutant List was the basis for most of the metals, inorganic, and organic constituents selected for the Urban Toxics and Nonpoint Source Evaluation Monitoring Projects. A much shorter list was adapted from USEPA Priority Pollutants to be used in the Industrial Monitoring and Lake Superior Demonstration Projects.

Polycyclic Aromatic Hydrocarbons (PAH's) analyzed prior to April 1994 are not included in this data summary. Samples collected before April 1994 were analyzed using a method which over-measured the actual PAH concentration, and which had a minimum reporting limit that was too high. Minimum reporting limits for most of the PAH's decreased dramatically after April 1994. For example, the reporting limit for benzo(a)pyrene changed from $5 \mu \mathrm{g} / \mathrm{L}$ to 0.002 $\mu \mathrm{g} / \mathrm{L}$.

\section{STORMWATER QUALITY}

Data from the four projects were used to determine summary statistics for concentrations of constituents that exceeded the minimum reported values for at 
Table 4. Constituents analyzed in stormwater from storm sewers and urban streams in Wisconsin

\begin{tabular}{|c|c|c|c|}
\hline Constituent & Project Number ${ }^{1}$ & Constituent & Project Number ${ }^{1}$ \\
\hline \multicolumn{4}{|c|}{ Conventional constituents } \\
\hline $\mathrm{pH}$ (standard units) & 2,4 & Suspended solids & $1,2,3,4$ \\
\hline BOD, 5-day at $20^{\circ} \mathrm{C}$ & 2,4 & Nitrite plus nitrate, dissolved & $2,3,4$ \\
\hline Coliform, fecal (colonies/100 milliliters) & 2,4 & Nitrogen, ammonia, dissolved & $2,3,4$ \\
\hline Hardness, dissolved & 2,4 & Nitrogen, ammonia, organic, total ${ }^{2}$ & $2,3,4$ \\
\hline Alkalinity, total as $\mathrm{CaCo}_{3}$ & 2,4 & Phosphate, ortho, dissolved & 2,4 \\
\hline Sulfate, dissolved & 4 & Carbon, organic & $1,2,4$ \\
\hline Chloride, dissolved & 2,4 & & \\
\hline \multicolumn{4}{|c|}{ Metals and cyanide } \\
\hline Antimony, total recoverable & $1,2,3,4$ & Cyanide, total & 1,2 \\
\hline Cadmium, dissolved & 2,4 & Selenium, total recoverable & 1,2 \\
\hline Chromium, total recoverable & $1,2,3,4$ & Silver, total recoverable & $1,2,3,4$ \\
\hline Chromium, dissolved $^{2}$ & 2 & Zinc, total recoverable & $1,2,3,4$ \\
\hline Copper, total recoverable & $1,2,3,4$ & Zinc dissolved & 2,4 \\
\hline Copper, dissolved & 2,4 & & \\
\hline \multicolumn{4}{|c|}{ Pesticides, total } \\
\hline Alachlor & 1,2 & Methoxychlor & 1,2 \\
\hline Aldrin & 1,2 & Methyl parathion & 1,2 \\
\hline Ametryne & 1,2 & Methyl trithion ${ }^{2}$ & 1,2 \\
\hline Atrazine & 1,2 & Metolachlor & 1,2 \\
\hline DDE & 1,2 & Parathion & 1,2 \\
\hline DDT & 1,2 & Pendimethalin & 2 \\
\hline DE-ethyl atrazine ${ }^{2}$ & 2 & Perthane & 1,2 \\
\hline DE-isopropyl atrazine ${ }^{2}$ & 2 & Phorate & 1,2 \\
\hline DEF & 1,2 & Picloram & 1,2 \\
\hline Diazinon & 1,2 & Prometon & 1,2 \\
\hline Dicamba & 1,2 & Prometryne & 1,2 \\
\hline Dieldrin & 1,2 & Propazine & 1,2 \\
\hline Dimethoate & 2 & Propham & 1,2 \\
\hline Disulfoton & 2 & Sevin & 1,2 \\
\hline Disyston & 1,2 & Silvex & 1,2 \\
\hline Endosulfan & 1,2 & Simazine & 1,2 \\
\hline Endrin & 1,2 & Simetryne & 1,2 \\
\hline Ethion & 1,2 & Toxaphene & 1,2 \\
\hline Heptachlor & 1,2 & Trifluralin & 1,2 \\
\hline Heptachlor epoxide & 1,2 & Trithion & 1,2 \\
\hline Isophorone & 1,2 & 2,4-D & 1,2 \\
\hline
\end{tabular}


Table 4. Constituents analyzed in stormwater from storm sewers and urban streams in Wisconsin-Continued

\begin{tabular}{|c|c|c|c|}
\hline Constituent & Project Number ${ }^{1}$ & Constituent & Project Number ${ }^{1}$ \\
\hline \multicolumn{4}{|c|}{ Pesticides, total-Continued } \\
\hline Lindane & 1,2 & $2,4,5-\mathrm{T}$ & 1,2 \\
\hline Methomyl & 1,2 & & \\
\hline \multicolumn{4}{|c|}{ PCB's and related compounds } \\
\hline Bis(2-chloroethoxy)methane & 1,2 & Hexachlorocyclopentadiene & 1,2 \\
\hline Hexachlorobutadiene & 1,2 & Hexachloroethane & 1,2 \\
\hline \multicolumn{4}{|c|}{ Ethers } \\
\hline 4-Bromophenyl phenyl ether & 1,2 & Bis(2-chloroethyl)ether & 1,2 \\
\hline 4-Chlorophenyl phenyl ether & 1,2 & Bis(2-chloroisopropyl)ether & 1,2 \\
\hline 1-3-Dichlorobenzene & 1,2 & Hexachlorobenzene & 1,4 \\
\hline 1,4-Dichlorobenzene & 1,2 & Nitrobenzene & 1,2 \\
\hline \multicolumn{4}{|c|}{ Phenols and cresols } \\
\hline 2,4,6-Trichlorphenol & 1,2 & 4,6-Dinitroorthocresol & 1,2 \\
\hline 2,4-Dichlorophenol & 1,2 & 4-Nitrophenol & 1,2 \\
\hline 2,4-Dimethylphenol & 1,2 & Parachlorometa cresol & 1,2 \\
\hline 2,4-Dinitrophenol & 1,2 & Pentachlorophenol & 1,2 \\
\hline 2-Chlorophenol & 1,2 & Phenol $(6 \mathrm{H}-50 \mathrm{H})$ & 1,2 \\
\hline 2-Nitrophenol & 1,2 & & \\
\hline \multicolumn{4}{|c|}{ Phthalate esters } \\
\hline Acenaphthylene & 2,4 & Fluoranthene & 2,4 \\
\hline Anthracene & 2,4 & Fluorene & 2,4 \\
\hline Benzo $[a]$ anthracene & 2,4 & Indeno pyrene & 2,4 \\
\hline Benzo $[a]$ pyrene & 2,4 & Naphthalene & 2,4 \\
\hline Benzo $[b]$ fluoranthene & 2,4 & Phenanthrene & 2,4 \\
\hline Benzo $[g h i]$ perylene & 2,4 & Pyrene & 2,4 \\
\hline \multicolumn{4}{|c|}{ Nitrosamines } \\
\hline$N$-nitrosodi- $n$-propylamine & 1,2 & $N$-nitrosodiphenylamine & 1,2 \\
\hline$N$-nitrosodimethylamine & 1,2 & & \\
\hline
\end{tabular}

${ }^{1}$ Refers to projects listed in table 1 .

${ }^{2}$ Constituent was not analyzed for in Wisconsin stormwater from urban streams. 
least 10 percent of the samples. These projects represent the most reliable event mean concentrations collected for Wisconsin stormwater between 1989 and 1994. Together the projects not only provided a significant number of event mean concentrations for each constituent, but also integrate the event mean concentrations from many types of land uses (table 1).

A check of laboratory analytical techniques used for each project indicated they were compatible enough to combine the data from the projects. Any questionable data were removed from the data set. Data for the storm sewers and urban streams were compiled separately.

Summary statistics by themselves did not describe the potential impact of the stormwater on the health of the receiving waters. Constituent levels were compared to Wisconsin surface-water and groundwater-quality standards to develop a list of contaminants that might adversely affect a receiving water. Ground-water standards were included because the construction of infiltration best management practices could increase the chance of ground-water contamination by the stormwater. Other evaluations of the constituent concentrations included a comparison of Wisconsin stormwater concentrations with those from other states, a comparison of storm sewer and urban stream concentrations, presentation of stormwater bioassay results, and a comparison of stormwater and lowflow concentrations in urban streams.

\section{Frequency of Detection of Constituents}

A frequency of detection of less than 10 percent was chosen as the cutoff for constituents to be included in the summary statistics and the evaluation of the potential impact of those constituents on the health of the receiving waters. Ten percent was judged to be a low enough percentage to include all important contaminants but high enough to reduce the list of contaminants deserving some attention to a manageable number. Similar analysis done by NURP investigators also used 10 percent as a cutoff for constituents deserving more discussion. The resulting data set had to contain at least three concentrations which were above the minimum reporting limit for the determination of summary statistics. Only DE ethyl atrazine in the storm sewers and total recoverable silver and 2,4-DP in the streams did not meet this criteria. These constituents were not included in the summary statistics.

\section{Storm Sewer Discharge}

Forty-eight percent of the constituents found in samples from the storm sewers were detected in 10 percent or more samples (table 5). Most of the constituents whose detection frequencies were greater than 10 percent were among 4 of the 11 types of constituents: conventional constituents, metals and inorganics, pesticides, and PAH's. The frequency of detection ranged from 10 to 99 percent for metals, inorganic, pesticides, and PAH's. The range for conventional constituents was from 88 to 100 percent. There were 76 constituents which were not detected in at least 10 percent of the samples. Most of these constituents were organic compounds that had a detection frequency of zero.

Although there was a wide range of detection frequency for the metals, inorganics, pesticides, and PAH's, each type of constituent tended to dominate one or two of the four ranges of detection frequencies (table 5). Event mean concentrations for PAH's dominated the 75 percent or more range of detection frequency. High frequency of occurrences for PAH's is not unexpected because they are formed in any hydrocarbon combustion process and may be released from spills of petroleum products (National Research Council of Canada, 1983). Important sources of PAH's include heat and power generation, refuse burning, industrial activities, and vehicle emissions. Only naphthalene, a relatively low-molecular-weight and therefore more volatile PAH, was not detected at all. Some loss of naphthalene could have occurred during sampling.

In contrast to the combined results of the four Wisconsin urban-runoff studies, results from the 28 cities monitored during NURP, and the NPDES monitoring in the Dallas-Fort Worth, Texas area did not show PAH's at detection frequencies of 75 percent or greater (U.S. Environmental Protection Agency, 1983; Brush and others, 1994). Those data sets include fewer types of PAH's above minimum reporting limits, and the frequency of detection for the ones found were always 10 to 19 percent. The minimum reporting limits in the NURP and Texas NPDES studies might have been too high to result in a high frequency of detection. This problem was also experienced by investigators doing the NPDES stormwater monitoring for cities in Wisconsin.

Differences in the results for PAH's points out the need to update lists of frequently detected constituents as analytical technology evolves. Future monitor- 
Table 5. Frequency of occurrence for constituents detected above minimum reporting limits in at least 10 percent of the Wisconsin storm sewer stormwater samples

\begin{tabular}{|c|c|}
\hline \multicolumn{2}{|c|}{ Detected in 75 percent or more of the samples } \\
\hline Chemical oxygen demand, COD (97) & Chromium, total recoverable (90) \\
\hline BOD, 5-day at $20^{\circ} \mathrm{C}(99)$ & Copper, dissolved (80) \\
\hline Coliform, fecal (colonies $/ 100 \mathrm{~mL}$ ) (94) & Copper, total recoverable (97) \\
\hline Hardness, dissolved (98) & Lead, total recoverable (97) \\
\hline Hardness, total (98) & Nickel, total recoverable (77) \\
\hline Alkalinity, total as $\mathrm{CaCo}_{3}(100)$ & Zinc, total recoverable (99) \\
\hline Sulfate, dissolved (85) & Zinc, dissolved (98) \\
\hline Chloride, dissolved (94) & Benzo $[a]$ anthracene (96) \\
\hline Suspended solids (99) & Benzo $[a]$ pyrene (97) \\
\hline Total solids (97) & Benzo[b]fluoranthene (97) \\
\hline Nitrite plus nitrate, dissolved (97) & Benzo[ghi]perylene (96) \\
\hline Nitrogen, ammonia, dissolved (98) & Benzo[ $k]$ fluoranthene $(97)$ \\
\hline Nitrogen, ammonia, organic, total (88) & Chrysene (93) \\
\hline Phosphorus, total (98) & Fluoranthene (97) \\
\hline Phosphate, ortho, dissolved (99) & Indeno Pyrene (93) \\
\hline Carbon, organic (98) & Phenanthrene (95) \\
\hline Cadmium, total recoverable (76) & Pyrene (96) \\
\hline \multicolumn{2}{|c|}{ Detected in 50 to 74 percent of the samples } \\
\hline Arsenic, total recoverable (70) & Atrazine (58) \\
\hline Cadmium, dissolved (56) & Bis(2-ethylhexyl)phthalate (51) \\
\hline 2,4-D (53) & Anthracene (73) \\
\hline \multicolumn{2}{|c|}{ Detected in 20 to 49 percent of the samples } \\
\hline Antimony, total recoverable (45) & Dicamba (30) \\
\hline Silver, total recoverable (24) & Diazinon (47) \\
\hline Lead, dissolved (23) & Malathion (20) \\
\hline Alachlor (35) & Methoxychlor (23) \\
\hline Chlordane (27) & Metolachlor (27) \\
\hline DDT (25) & 1,2,5,6-Dibenzanthracene (25) \\
\hline \multicolumn{2}{|c|}{ Detected in 10 to 19 percent of the samples } \\
\hline Cyanide (12) & Heptachlor epoxide (10) \\
\hline 2,4-DP (11) & Lindane (16) \\
\hline Aldrin (10) & Picloram (11) \\
\hline Cyanazine (18) & Prometone (14) \\
\hline DDD (13) & PCB (12) \\
\hline $\operatorname{DDE}(17)$ & Acenaphthene (18) \\
\hline DE-ethyl atrazine (17) & Acenaphthylene (18) \\
\hline Endosulfan (10) & Fluorene (18) \\
\hline Hepetachlor (10) & \\
\hline
\end{tabular}


ing efforts might include additional constituents because the technology probably will be developed which will lower the minimum reporting limits for certain constituents. Reevaluation of target constituents can be especially important if the previous minimum reporting limits were greater than a concentration that may be harmful to aquatic life.

Of the 16 metals and cyanide, 8 were detected in 75 percent or more of the samples. Measurable concentrations of total recoverable zinc, copper, and lead were detected in 75 percent or more of the samples. Many sources of these metals exist in urban areas. Galvanized roofing materials are a source of zinc (Bannerman and others, 1993), as are automobile tires (FHWA, 1984).

Copper is derived from man-made sources, such as automobile brakes, but it has also been shown to originate from natural sources, as in the Santa Clara Valley in California (Cooke and others, 1994). Even though lead has been removed from most gasoline, some sources of the metal exist. For example, high concentrations of lead can be found in engine oil, and lead is still used in road paint.

Comparison of NPDES monitoring results from Texas with the Wisconsin stormwater-monitoring results showed the same number of total recoverable metals in 75 percent or more of the samples. In the NURP data sets, more of the metals were at lower frequencies of detection, but most were still found in more than 10 percent of the samples. Measurable concentrations of dissolved zinc and copper have been frequently detected in stormwater samples from both Wisconsin and Santa Clara Valley (Cooke and others, 1994).

Twenty-one pesticides were detected at a frequency between 10 and 60 percent. Lawn-care activities may be a source for many of these pesticides. A banned pesticide, DDT, and a restricted-use pesticide, chlordane, were detected in the stormwater. (DDT is still being used in large quantities in other countries.) Chlordane was also detected by NURP and by the NPDES monitoring in the Dallas-Fort Worth, Texas area. Diazinon concentrations exceeded minimum reporting limits in 47 percent of the samples for Wisconsin. Diazinon detections were in the range of 50 to 75 percent for data collected in Texas. In a survey of homeowners in Madison, Wis., diazinon was the most commonly used insecticide among the homeowners who used an insecticide (Kroupa and Associates, 1995). Two herbicides commonly used for lawn care, 2,4-D and dicamba, were detected in about 50 percent of Wisconsin stormwater samples. These same two pesticides were also frequently detected in storm-sewer discharge to a lake in Minneapolis, Minn. (Wotzka and others, 1994). More surprising was the high detection frequency for four herbicides not registered for lawn care in urban areas. Atrazine, alachlor, cyanazine, and metolachlor are some of the most commonly used herbicides on major row crops, such as corn and soybeans. These four herbicides were detected in runoff from 43 percent of the monitored events in the Minneapolis study. Analysis of rainfall in Minnesota indicates that these herbicides are being transported in the atmosphere and deposited in urban areas by rain (Lin and others, 1994).

\section{Urban Streamwater}

Fifty percent of the constituents tested for in urban-streamwater samples were detected at frequencies of 10 percent or greater. Similar to the storm sewers, nearly all of the constituents detected for at least 10 percent of the samples were represented by four types: conventional constituents, metals and inorganics, pesticides, and PAH's. Frequency of detections ranged from 10 to 100 percent for the metals, inorganic, and organic constituents and 92 to 100 percent for the conventional constituents. As with the storm-sewer samples, the constituents were divided into four ranges of detection frequencies (table 6). Metals, PAH's, and conventional constituents were the only types of constituents whose concentrations exceeded minimum reporting limits in 75 percent or more of the samples. Pesticides were the most represented type of constituent at detection frequencies of 20 to 49 percent. Not only did streams and storm sewers have the same types of constituents detected in samples at least 10 percent of the time, but many of the constituents fell into the same frequency ranges. This was especially true for the constituents detected in 75 percent or more of the samples. Most of the constituents not meeting the 10 percent cutoff were organic compounds with a detection frequency of zero.

\section{Constituent Concentrations}

\section{Statistical Analysis of All Data}

Summary statistics were determined for the constituents detected in at least 10 percent of the stormwater samples collected from both storm sewers and 
Table 6. Frequency of occurrence for constituents detected above minimum reporting limits in at least 10 percent of the Wisconsin urban stream stormwater samples

\begin{tabular}{|c|c|}
\hline \multicolumn{2}{|c|}{ Detected in 75 percent or more of the samples } \\
\hline Chemical oxygen demand, COD (92) & Copper, total recoverable (93) \\
\hline $\mathrm{BOD}, 5$-day at $20^{\circ} \mathrm{C}(96)$ & Lead, total recoverable $(93)$ \\
\hline Coliform, fecal (colonies/100 mL) (94) & Nickel, total recoverable $(100)$ \\
\hline Hardness, dissolved (98) & Zinc, total recoverable (86) \\
\hline Hardness, total (100) & Zinc, dissolved (98) \\
\hline Alkalinity, total as $\mathrm{CaCo}_{3}(100)$ & Anthracene (88) \\
\hline Sulfate, dissolved (100) & Benzo $[a]$ anthracene $(100)$ \\
\hline Chloride, dissolved (98) & Benzo[a]pyrene (100) \\
\hline Suspended solids (98) & Benzo $[b]$ fluoranthene $(100)$ \\
\hline Total solids (97) & Benzo[ghi]perylene (100) \\
\hline Nitrite plus nitrate, dissolved (98) & Benzo $[k]$ fluoranthene $(100)$ \\
\hline Nitrogen, ammonia, dissolved (97) & Chrysene (100) \\
\hline Phosphorus, total (97) & Fluoranthene (100) \\
\hline Phosphate, ortho, dissolved (92) & Indeno Pyrene (100) \\
\hline Carbon, organic $(95)$ & Phenanthrene (90) \\
\hline Arsenic, total recoverable $(91)$ & Pyrene (100) \\
\hline Chromium, total recoverable (86) & \\
\hline
\end{tabular}

Chromium, total recoverable (86)

\begin{tabular}{ll}
\hline & Detected in 50 to 74 percent of the samples \\
\hline Antimony, total recoverable (50) & Fluorene (67) \\
Cadmium, dissolved (50) & Naphthalene (50) \\
Cadmium, total recoverable (54) & $2,4-D$ (53) \\
Copper, dissolved (74) & Atrazine (59) \\
1,2,5,6 Dibenzanthracene (65) & DDD (53) \\
Acenaphthene (62) & DDE (53) \\
Acenaphthylene (69) & DDT (47) \\
\hline & Detected in 20 to 49 percent of the samples \\
\hline Alachlor (24) & Malathion (32) \\
Aldrin (27) & Mirex (20) \\
Diazinon (38) & Naphthalene (20) \\
Dicamba (35) & Perthane (20) \\
Dieldrin (20) & Prometone (22) \\
Endosulfan (20) & Simazine (22) \\
Endrin (20) & Toxaphene (20) \\
Heptachlor (20) & PCB (20) \\
Heptachlor epoxide (20) & Bis(2-ethylhexyl)phthalate (33) \\
\hline & Detected in 10 to 19 percent of the samples \\
\hline Lead dissolved (16) & Chlordane (10) \\
Silver total recoverable (14) & Methoxychlor (19) \\
2,4-DP (13) & \\
\hline
\end{tabular}


urban streams (tables 7 and 8). All the statistics were calculated for event mean concentrations. For a measure of central tendency, the median and mean were calculated. Coefficients of variation were used to represent the variability between storm events and site-tosite variability. The minimum reporting limits were provided by the two laboratories responsible for the analysis.

The inclusion of many censored values (measurements below the minimum reporting limit) in the calculation of summary statistics required a log-probability regression procedure be used to estimate the mean of data sets containing less-than values. The method estimates the censored values on the basis of a lognormal probability distribution and uses the estimated values and the uncensored data for estimation of a mean (Helsel and Hirsch, 1995). No estimated values were used to determine the median; the data were ranked in ascending order. If more than 50 percent of the concentrations were less-than values, the median was given the minimum reporting limit.

Log normality tests performed for selected constituents, with a few exceptions, characterized the event mean concentration as log normally distributed. Similar results have been reported by other investigations (U.S. Environmental Protection Agency, 1983; FHWA, 1990). Data that was log normally distributed was considered best represented by the median. Whenever possible, medians were used to evaluate the effect of stormwater on water quality.

If the stormwater concentrations are used to calculate the cumulative effects of seasonal or annual loadings, the means are probably a more accurate statistic to use to calculate loadings. Loadings have been used to assess the impact of stormwater on lakes and to determine the critical sources of each constituent.

Because the means were always higher than the medians, the mean might better represent the loading for storms with much higher concentrations. Means also have been used to calculate loadings in stormwater models, such as the Source Loading and Management Model (SLAMM) (Pitt, 1994).

The coefficients of variability seemed high for many of the constituents. About 46 percent of the coefficients of variation for storm sewers were approximately two or greater. To help understand the source of high variability, an analysis was done on the site-to-site variability.

\section{Site-to-Site Variability}

An analysis of variance (ANOVA) (Helsel and Hirsch, 1995) test was done to determine whether the geometric means of the constituent concentrations were significantly different among two or more of the storm-sewer sites. If the means were significantly different, a Tukey multiple-comparison test was done to determine which sites were significantly different from each other (Helsel and Hirsch, 1995). To make the sample sizes more nearly equivalent between sites, the industrial-site data were aggregated, and the data from the three mixed sites also were aggregated. Data for suspended solids, total phosphorus, total recoverable zinc, copper, and lead were tested for significant differences. Total phosphorus data were not tested for all the sites because total phosphorus was not available for Hastings Street. Results from the ANOVA test showed significant differences between sites for all the constituents. Variability in the summary statistics would have been reduced by not aggregating the data.

Definite patterns were found amongst the geometric mean data (fig. 1). The Tukey test indicated that the commercial sites, mixed sites, and the industrial park tended to have similar geometric means. The residential site and industrial sites have similar geometric means. For all the constituents, either the residential site or the industrial sites had significantly lower geometric means than all other sites. The significantly higher geometric means were generally among the commercial, mixed, and industrial-park sites. These results agree with box plots of the same data (fig. 1).

If more sites were available for each type of land use, these tests could be used to determine the differences between land uses. At best, the results represent a preliminary look at which land uses tend to have the highest or lowest event mean concentrations of contaminants. Other stormwater-monitoring projects have evaluated differences between land uses, but multiple sites represented each land use in those projects. For example, 4 to 39 sites represented each land use in the NURP study. Results from NURP showed no significant differences in event mean concentrations between land uses except for open space. In contrast, metals concentrations in stormwater from residential and commercial sites were found to be significantly different than those from heavy industrial sites in Santa Clara Valley (Cooke and others, 1994). 
Table 7. Summary statistics for event mean concentrations of constituents with detection frequencies of at least 10 percent at Wisconsin storm-sewer-monitoring sites

[CV, coefficient of variation; $\mathrm{mg} / \mathrm{L}$, milligrams per liter; $\mu \mathrm{g} / \mathrm{L}$, micrograms per liter; $\mathrm{mL}$, milliliter; <, less than]

\begin{tabular}{|c|c|c|c|c|c|c|c|}
\hline Constituent & $\begin{array}{l}\text { Minimum } \\
\text { reporting } \\
\text { limits }\end{array}$ & $\begin{array}{l}\text { Number of } \\
\text { samples }\end{array}$ & Maximum & Minimum & Median $^{1}$ & Mean & CV \\
\hline \multicolumn{8}{|c|}{ Conventional constituents ( $\mathrm{mg} / \mathrm{L}$, unless otherwise noted) } \\
\hline $\mathrm{pH}$ (standard units) & 0.1 & 131 & 8.11 & 5.63 & 7.3 & 7.24 & 0.0579 \\
\hline Chemical oxygen demand, COD & 5 & 97 & 310 & $<5$ & 48 & 69 & .86 \\
\hline BOD, 5-day at $20^{\circ} \mathrm{C}$ & 1 & 112 & 210 & $<1$ & 9.4 & 18 & 1.5 \\
\hline Coliform, fecal (colonies/100 mL) & 10 & 54 & 370,000 & $<10$ & 6,500 & 30,000 & 2.3 \\
\hline Hardness, dissolved & 6 & 173 & 220 & $<6$ & 26 & 33 & .79 \\
\hline Hardness, total & 6 & 209 & 900 & 3 & 51 & 87 & 1.3 \\
\hline Alkalinity, total as $\mathrm{CaCo}_{3}$ & $.5-1$ & 82 & 149 & 2 & 34.5 & 40.7 & .66 \\
\hline Sulfate, dissolved & 1 & 26 & 23 & $<1$ & 9 & 9.1 & .67 \\
\hline Chloride, dissolved & $.01-1$ & 94 & 1,000 & $<.01$ & 10 & 64 & 2.5 \\
\hline Suspended solids & 2 & 247 & 1,850 & $<2$ & 120 & 237 & 1.31 \\
\hline Total solids & 10 & 167 & 2,810 & $<10$ & 256 & 386 & 1.06 \\
\hline Nitrite plus nitrate, dissolved & .01 & 147 & 73.6 & $<.01$ & .493 & 1.1 & 5.5 \\
\hline Nitrogen, ammonia, dissolved & $.005-.01$ & 102 & 1.3 & $<.01$ & .24 & .3 & .83 \\
\hline Nitrogen, ammonia, organic, total & .2 & 34 & 34 & $<.2$ & 1 & 1.8 & 1.9 \\
\hline Phosphorus, total & $.01-.02$ & 204 & 3.8 & $<.02$ & .29 & .45 & .49 \\
\hline Phosphate, ortho, dissolved & .002 & 137 & 3.31 & $<.002$ & .09 & .178 & 1.93 \\
\hline Carbon, organic total & .5 & 100 & 66 & $<.5$ & 11 & 16 & .89 \\
\hline \multicolumn{8}{|c|}{ Metals and inorganics $(\mu \mathrm{g} / \mathrm{L})$} \\
\hline Antimony, total recoverable & $1-5$ & 74 & 4 & $<1$ & $<1$ & 1.2 & 6 \\
\hline Arsenic, total recoverable & $1-10$ & 71 & 5 & $<1$ & 1 & 1.1 & .9 \\
\hline Cadmium, total recoverable & $.2-1$ & 197 & 7 & $<.2$ & .5 & .89 & 1 \\
\hline Cadmium, dissolved & .2 & 89 & 3.8 & $<.2$ & .08 & 3 & 2 \\
\hline Chromium, total recoverable & $1-3$ & 164 & 90 & $<3$ & 7 & 11 & 1.1 \\
\hline Copper, total recoverable & $1-3$ & 223 & 210 & $<3$ & 18 & 26 & .96 \\
\hline Copper, dissolved & $1-3$ & 120 & 33 & $<3$ & 5 & 6.5 & .9 \\
\hline Cyanide, total & .01 & 59 & .09 & $<.01$ & $<.01$ & .005 & 2.5 \\
\hline Lead, total recoverable & $1-3$ & 230 & 570 & $<1$ & 24 & 48 & 1.4 \\
\hline Lead, dissolved & $1-3$ & 120 & 13 & $<1$ & $<3$ & .87 & 1.8 \\
\hline Nickel, total recoverable & $1-10$ & 81 & 52 & $<1$ & 5 & 8.3 & 1.1 \\
\hline Silver, total recoverable & $.5-5$ & 129 & 52 & $<.5$ & $<.5$ & 1.9 & 3.6 \\
\hline Zinc, total recoverable & 10 & 249 & 1,500 & $<10$ & 150 & 200 & .86 \\
\hline Zinc, dissolved & 10 & 135 & 840 & $<10$ & 70 & 89 & 1 \\
\hline \multicolumn{8}{|c|}{ Pesticides $(\mu \mathrm{g} / \mathrm{L})$} \\
\hline Alachlor & $.1-1.7$ & 79 & 2.9 & $<.1$ & $<.25$ & .36 & 1.4 \\
\hline Atrazine & $.1-.15$ & 79 & 6.5 & $<.1$ & .1 & .26 & 3.2 \\
\hline Chlordane & $.05-3$ & 98 & 1 & $<.05$ & $<.1$ & .086 & 2.3 \\
\hline Cyanazine & $.1-.55$ & 79 & 1.9 & $<0.1$ & $<0.1$ & 0.13 & 2.3 \\
\hline DDD & $.01-.1$ & 52 & .1 & $<.01$ & $<.01$ & .01 & 2.6 \\
\hline DDE & $.01-.1$ & 52 & .1 & $<.01$ & $<.01$ & .01 & 2.7 \\
\hline DDT & $.01-.1$ & 52 & .1 & $<.01$ & $<.01$ & .013 & 2.1 \\
\hline
\end{tabular}


Table 7. Summary statistics for event mean concentrations of constituents with detection frequencies of at least 10 percent at Wisconsin storm-sewer-monitoring sites-Continued

\begin{tabular}{|c|c|c|c|c|c|c|c|}
\hline Constituent & $\begin{array}{l}\text { Minimum } \\
\text { reporting } \\
\text { limits }\end{array}$ & $\begin{array}{l}\text { Number of } \\
\text { samples }\end{array}$ & Maximum & Minimum & Median ${ }^{1}$ & Mean & CV \\
\hline \multicolumn{8}{|c|}{ Pesticides $(\mu \mathrm{g} / \mathrm{L})-$ Continued } \\
\hline Diazinon & $.01-1$ & 87 & 2.2 & $<.01$ & $<1$ & .11 & .71 \\
\hline Dicamba & $.01-2.9$ & 83 & .5 & $<.01$ & $<.22$ & .06 & 1.8 \\
\hline Endosulfan & $.01-.1$ & 52 & .1 & $<.01$ & $<.01$ & .013 & 2 \\
\hline Heptachlor & $.01-.1$ & 52 & .1 & $<.01$ & $<.01$ & .013 & 2 \\
\hline Heptachlor epoxide & $.01-.1$ & 52 & .1 & $<.01$ & $<.01$ & .013 & 2 \\
\hline Lindane & $.01-.4$ & 80 & .1 & $<.01$ & $<.01$ & .0084 & 2.8 \\
\hline Malathion & $.01-1.2$ & 86 & 1.1 & $<.01$ & $<.2$ & .023 & 5.4 \\
\hline Methoxychlor & $.01-2$ & 80 & .5 & $<.01$ & $<.04$ & .023 & 3 \\
\hline Metolachlor & $.01-1.1$ & 48 & .7 & $<.1$ & $<.1$ & .12 & 1.4 \\
\hline Picloram & $.01-.1$ & 54 & .2 & $<.01$ & $<.1$ & .036 & 1.3 \\
\hline Prometon & .1 & 42 & .5 & $<.1$ & $<.1$ & .045 & 2 \\
\hline 2,4-D & $.01-7.8$ & 83 & 10 & $<0.01$ & 0.1 & .99 & 1.9 \\
\hline 2,4-DP & $.01-1$ & 54 & 1.2 & $<.01$ & $<.1$ & .07 & 3.2 \\
\hline \multicolumn{8}{|c|}{ PCB's and related compounds $(\mu \mathrm{g} / \mathrm{L})$} \\
\hline PCB & $.01-1$ & 52 & 1 & $<0.1$ & $<0.1$ & 0.11 & 2.3 \\
\hline \multicolumn{8}{|c|}{ Phthalate esters $(\mu \mathrm{g} / \mathrm{L})$} \\
\hline Bis(2-ethylhexy)phthalate & 5 & 49 & 150 & $<5$ & 5 & 13 & 2.1 \\
\hline \multicolumn{8}{|c|}{ Polycyclic aromatic hydrocarbons $(\mu \mathrm{g} / \mathrm{L})$} \\
\hline Acenaphthene & $.05-3.4$ & 26 & 6 & $<0.05$ & $<3.4$ & 0.31 & 3.8 \\
\hline Acenaphthylene & $.05-8.2$ & 22 & .27 & $<.05$ & .075 & .1 & .63 \\
\hline Anthracene & $.05-.12$ & 26 & 19 & $<.12$ & .23 & 1.2 & 3.2 \\
\hline Benzo $[a]$ anthracene & .003 & 25 & 23 & $<.003$ & 0.9 & 2.1 & 2.2 \\
\hline Benzo $[a]$ pyrene & .002 & 30 & 16 & $<.002$ & 1.3 & 2.3 & 1.4 \\
\hline Benzo $[b]$ flouranthene & .0045 & 30 & 23 & $<.0045$ & 1.4 & 2.7 & 1.6 \\
\hline Benzo $[g h i]$ perylene & $.0047-.01$ & 26 & 15 & $<.0047$ & 1 & 2 & 1.6 \\
\hline Benzo $[k]$ flouranthene & .0034 & 29 & 14 & $<.0034$ & .88 & 1.7 & 1.5 \\
\hline Chrysene & .023 & 30 & 24 & $<.023$ & 1.4 & 2.8 & 1.6 \\
\hline Fluoranthene & $.0087-.01$ & 30 & 88 & $<.009$ & 3.2 & 8.6 & 1.9 \\
\hline Fluorene & $.05-.6$ & 25 & 7 & $<.05$ & $<.6$ & .41 & 3.5 \\
\hline Indeno Pyrene & .02 & 28 & 17 & $<.02$ & 1.4 & 2.4 & 1.4 \\
\hline Phenanthrene & .17 & 24 & 52 & $<.17$ & 1.6 & 4.6 & 2.5 \\
\hline Pyrene & $.00065-.01$ & 27 & 66 & $<.007$ & 1.8 & 5.8 & 2.2 \\
\hline
\end{tabular}

${ }^{1}$ Medians were below the minimum reporting values when more than 50 percent of the observations were less than the minimum reporting limit. 
Table 8. Summary statistics for event mean concentrations of constituents with detection frequencies of at least 10 percent in four urban Wisconsin streams

[CV, coefficient of variation; $\mathrm{mg} / \mathrm{L}$, milligrams per liter; $\mu \mathrm{g} / \mathrm{L}$, micrograms per liter; $\mathrm{mL}$, milliliter; $<$, less than]

\begin{tabular}{|c|c|c|c|c|c|c|c|}
\hline Constituent & $\begin{array}{l}\text { Minimum } \\
\text { reporting } \\
\text { limits }\end{array}$ & $\begin{array}{l}\text { Number of } \\
\text { samples }\end{array}$ & Maximum & Minimum & Median 1 & Mean & cv \\
\hline \multicolumn{8}{|c|}{ Conventional constituents (mg/L) } \\
\hline $\mathrm{pH}$ (standard units) & .1 & 113 & 8.4 & 6.8 & 7.92 & 7.9 & 0.0369 \\
\hline Chemical oxygen demand, COD & $5-25$ & 38 & 120 & 5 & 38 & 40 & .53 \\
\hline BOD, 5 -day at $20^{\circ} \mathrm{C}$ & 1 & 82 & 22 & $<1$ & 6.5 & 7.5 & .59 \\
\hline Coliform, fecal (colonies/100 mL) & 10 & 32 & 800,000 & $<10$ & 12,000 & 42,000 & 3.4 \\
\hline Hardness, dissolved & 6 & 178 & 480 & $<6$ & 200 & 200 & .54 \\
\hline Hardness, total & 6 & 213 & 460 & $<6$ & 220 & 230 & .43 \\
\hline Alkalinity & $.5-1$ & 69 & 255 & 51 & 129 & 135 & .425 \\
\hline Chloride, dissolved & $.01-1$ & 93 & 1,000 & 5 & 64 & 120 & 1.4 \\
\hline Suspended solids & $1-2$ & 131 & 1,120 & $<2$ & 107 & 152 & 1.05 \\
\hline Total solids & $1-10$ & 109 & 2,100 & 196 & 472 & 533 & .501 \\
\hline Nitrite plus nitrate, dissolved & $.01-.005$ & 101 & 1.53 & 0.289 & .695 & 9.68 & .443 \\
\hline Nitrogen, ammonia, dissolved & $.002-.01$ & 92 & .87 & $<.005$ & .088 & .14 & 1 \\
\hline Phosphate, ortho, dissolved & $.001-.01$ & 114 & .109 & $<.002$ & .0275 & .0283 & .71 \\
\hline Phosphorus, total & $.001-.02$ & 124 & .81 & $<.01$ & .18 & .21 & .69 \\
\hline Carbon organic total & $.1-.5$ & 21 & 48 & 3.2 & 13 & 16 & .73 \\
\hline \multicolumn{8}{|c|}{$\underline{\text { Metals and inorganics }(\mu \mathrm{g} / \mathrm{L})}$} \\
\hline Antimony, total recoverable & 1 & 22 & 3 & $<1$ & $<1$ & .94 & .69 \\
\hline Arsenic, total recoverable & 1 & 22 & 3 & $<1$ & 1 & 1.4 & .51 \\
\hline Cadmium, total recoverable & $.2-1$ & 90 & 9 & $<.2$ & $<1$ & .57 & 1.9 \\
\hline Cadmium, dissolved & $.04-.2$ & 56 & 2.6 & $<.04$ & $<.2$ & .14 & 2.9 \\
\hline Chromium, total recoverable & $1-3$ & 90 & 60 & $<3$ & 6 & 8.9 & 1 \\
\hline Copper, total recoverable & $1-3$ & 131 & 140 & $<3$ & 14 & 17 & .98 \\
\hline Copper, dissolved & $1-3$ & 94 & 11 & $<3$ & 3.8 & 4 & .5 \\
\hline Lead, dissolved & $1-3$ & 94 & 2 & $<1$ & $<1$ & .76 & .49 \\
\hline Lead, total recoverable & $1-3$ & 131 & 340 & $<3$ & 17 & 27 & 1.4 \\
\hline Nickel, total recoverable & $1-10$ & 22 & 36 & 3 & 7 & 9.5 & .81 \\
\hline Zinc, total recoverable & 10 & 130 & 670 & $<10$ & 77 & 93 & .95 \\
\hline Zinc, dissolved & $.5-10$ & 84 & 160 & $<10$ & 26 & 33 & .75 \\
\hline \multicolumn{8}{|c|}{ Pesticides $(\mu \mathrm{g} / \mathrm{L})$} \\
\hline Alachlor & $.1-.7$ & 34 & .54 & $<.1$ & $<.1$ & .081 & 1.5 \\
\hline Aldrin & $.01-.1$ & 15 & .1 & $<.01$ & $<.01$ & .025 & 1.6 \\
\hline Atrazine & .1 & 34 & .5 & $<.1$ & .13 & .18 & .76 \\
\hline DDD & $.01-1$ & 15 & .1 & $<.01$ & .01 & .026 & 1.5 \\
\hline DDE & $.01-1$ & 15 & .1 & $<.01$ & .01 & .026 & 1.5 \\
\hline DDT & $.01-1$ & 15 & .1 & $<.01$ & $<.1$ & .027 & 1.5 \\
\hline Diazinon & $.01-1$ & 34 & .12 & $<.01$ & $<.5$ & .018 & 1.5 \\
\hline Dicamba & $.01-.8$ & 34 & .49 & $<.01$ & $<.01$ & .062 & 1.5 \\
\hline Methoxychlor & $.01-1$ & 31 & .1 & $<.01$ & $<.04$ & .012 & 2.4 \\
\hline Prometon & .1 & 18 & .36 & $<.1$ & $<.1$ & .067 & 1.3 \\
\hline $2,4-D$ & $.01-2$ & 34 & 4.1 & $<.01$ & .22 & .85 & 1.2 \\
\hline Simazine & .1 & 18 & 5.9 & $<.1$ & $<.1$ & .38 & 3.7 \\
\hline
\end{tabular}


Table 8. Summary statistics for event mean concentrations of constituents with detection frequencies of at least 10 percent in four urban Wisconsin streams-Continued

\begin{tabular}{|c|c|c|c|c|c|c|c|}
\hline Constituent & $\begin{array}{l}\text { Minimum } \\
\text { reporting } \\
\text { limits }\end{array}$ & $\begin{array}{l}\text { Number of } \\
\text { samples }\end{array}$ & Maximum & Minimum & Median ${ }^{1}$ & Mean & CV \\
\hline \multicolumn{8}{|c|}{ Phthalate esters $(\mu \mathrm{g} / \mathrm{L})$} \\
\hline Bis(2-ethylhexy)phthalate & 5 & 15 & 23 & $<5$ & $<5$ & 4.5 & 1.3 \\
\hline \multicolumn{8}{|c|}{ Polycyclic aromatic hydrocarbons ( $\mu \mathrm{g} / \mathrm{L}$ ) } \\
\hline 1,2,5,6-Dibenzanthracene & $.01-.05$ & 20 & 1.3 & $<.05$ & .18 & .32 & 1.2 \\
\hline Acenaphthene & .05 & 16 & .87 & $<.05$ & .08 & .14 & 1.5 \\
\hline Acenaphthylene & .05 & 16 & .27 & $<.05$ & .075 & .1 & .63 \\
\hline Anthracene & .05 & 16 & 15 & $<.05$ & .25 & 1.2 & 3.1 \\
\hline Benzo $[a]$ anthracene & .003 & 16 & 4.8 & .09 & .56 & .99 & 1.2 \\
\hline Benzo[a]pyrene & .002 & 16 & 4.3 & .07 & .78 & 1.1 & 1.1 \\
\hline Benzo $[b]$ fluoranthene & .0045 & 16 & 5.2 & .07 & 1 & 1.4 & 1.1 \\
\hline Benzo[ghi]perylene & $.0047-.01$ & 16 & 3.9 & .07 & .59 & .98 & 1.2 \\
\hline Benzo $[k]$ fluoranthene & .0034 & 16 & 4.9 & .06 & .57 & 1 & 1.3 \\
\hline Chrysene & .02 & 16 & 6.4 & .16 & .93 & 1.6 & 1 \\
\hline Fluoranthene & $.0087-.01$ & 12 & 11 & .31 & 2.8 & 3.4 & .89 \\
\hline Fluorene & $.05-.6$ & 12 & .37 & $<.05$ & .12 & .13 & .73 \\
\hline Indeno pyrene & .02 & 16 & 4.4 & .05 & .62 & 1 & 1.2 \\
\hline Naphthalene & .05 & 16 & .13 & $<.05$ & .054 & .058 & .55 \\
\hline Phenanthrene & .17 & 16 & 13 & .07 & 1 & 2 & 1.6 \\
\hline Pyrene & $.0065-.01$ & 16 & 13 & .27 & 2.2 & 3.2 & 1 \\
\hline
\end{tabular}

${ }^{1}$ Medians were below minimum reporting values when more than 50 percent of the observations were less than the minimum reporting limit.

\section{Potential Contaminants}

A list of potential contaminants was developed for Wisconsin stormwater. The purpose of the list is to target the constituents most likely to affect the health of both surface waters and ground water. At this early stage in our understanding of how each constituent might affect the receiving waters, it was decided to exclude as few of the constituents as possible. Future studies will hopefully make it possible to shorten the list. These thoughts led to a relatively conservative criterion for potential contaminants. The criterion for potential contaminants is a constituent detected in at least 10 percent of the samples and a constituent that exceeds a water-quality standard for at least one stormwater sample.

Ground-water-quality standards were considered in the criterion because infiltration of stormwater, especially by the implementation of infiltration best management practices, is a potential threat to ground-water quality. Constituents such as chloride, are already increasing in drinking-water wells (City of Madison,
1994). Calculated leaching rates for selected metals, pesticides, and PAH's indicated that these constituents have some degree of mobility in the soil column (Armstrong and Llano, 1992). As a group, metals, such as lead and copper, had much lower leaching rates through the unsaturated soil zone than the PAH's and pesticides, such as diazinon and 2,4-D. Opportunities for ground-water contamination will increase as many more infiltration devices are constructed.

Probability distributions (Helsel and Hirsch, 1995) of event mean concentrations for storm-sewer and stream samples were compared to both surfacewater- and ground-water-quality standards for Wisconsin. Levels of metals, inorganics, pesticides, PAH's, Bis(2-ethylhexyl)phthalate, and PCB's were compared to surface-water-quality criteria listed in a Wisconsin Administrative Code entitled "Surface Water Criteria for Toxic Substances" (Wisconsin Department of Natural Resources, 1989, NR105). Results of the comparison show that the probability of two metals, nine PAH's, and DDT exceeding the water-quality criteria in the stormwater from storm sewers is very high 

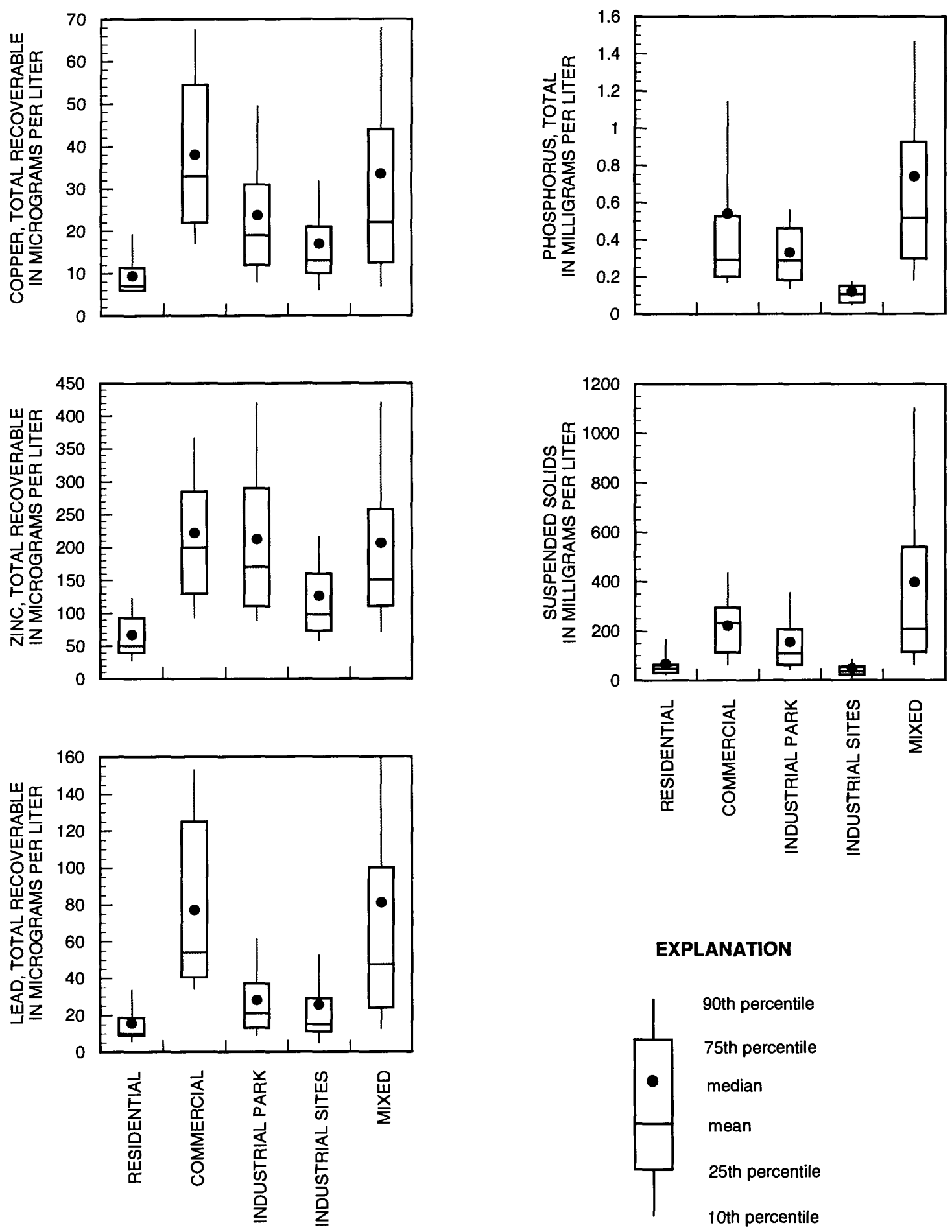

\section{EXPLANATION}

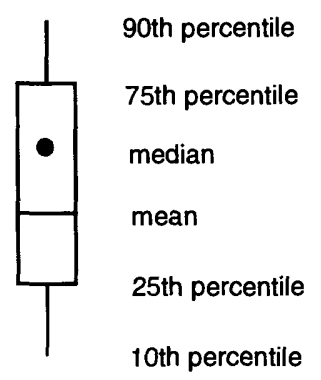

Figure 1. Differences in concentrations of selected constituents of urban stormwater in Wisconsin, by land use. 
(table 9). Event mean concentrations observed nationwide during NURP also exceeded water-quality criteria for metals and PAH's. Although the metal criteria are compared to total recoverable metals concentration, the event mean concentration of dissolved copper, zinc, and cadmium also exceeded the criteria with probabilities of 23,89 , and 3 percent, respectively.

Streamwater, like storm-sewer event mean concentrations, had a high probability of exceeding waterquality criteria for PAH's and DDT; unlike storm sewers, streamwater had a low probability of exceeding any acute toxicity criteria for metals.

For a number of the constituents detected in more than 10 percent of the samples, including pesticides such as diazinon and atrazine, surface-waterquality criteria have not been established. It has been recommended, however, that the diazinon concentration in the aquatic environment not exceed $0.80 \mu \mathrm{g} / \mathrm{L}$ (Arthur and others, 1983). The mean diazinon concentration found in the storm-sewer samples was 0.11 $\mu \mathrm{g} / \mathrm{L}$, and the maximum was $2.2 \mu \mathrm{g} / \mathrm{L}$. The probability of the diazinon event mean concentration in the storm sewer exceeding the recommended level was 4 percent.

Bacteria, suspended solids, and total phosphorus, and 5-day BOD were conventional constituents that also exceeded recommended levels in surface water. Fecal coliform counts for both storm sewer and streams exceeded the Wisconsin recreational body-contact bacteria standard of 400 counts per $100 \mathrm{~mL}$ in almost all samples (Wisconsin Department of Natural Resources, 1989, chap. NR102). Suspended-solids, 5-day BOD and total-phosphorous concentrations exceeded Wisconsin's permitted effluent limits (Wisconsin Department of Natural Resources, 1987, chap. NR-210) for about 97,5 , and 9 percent of the storm-sewer samples, respectively (table 9 ).

Although Wisconsin does not have an approved surface-water standard for chloride, trends of increasing chloride concentration indicate chloride has the potential to be a problem in Wisconsin surface waters. Records kept by the city of Madison show the chloride concentrations in Lakes Mendota (9,842 acres) and Wingra ( 345 acres) increased from 3 and $5 \mathrm{mg} / \mathrm{L}$, respectively, to 32 and $75 \mathrm{mg} / \mathrm{L}$, respectively, from 1940 to 1994 (City of Madison, 1994). Chloride concentration in Lake Mendota has been increasing about $1 \mathrm{mg} / \mathrm{L}$ each year for the last 10 years.

The probability of event mean concentration exceeding the enforcement level of the ground-waterquality standards was determined for metals, inorgan- ics, PAH's, PCB's, phthalates, pesticides, and conventional constituents (Wisconsin Department of Natural Resources, Chap. NR140, 1994). Six of the constituents analyzed in storm-sewer samples exceeded the ground-water standard for at least one storm event (table 9). Two of the constituents, Bis(2-ethylhexyl)phthalate and chloride, exceeded the groundwater standard in stormwater from both storm sewers and urban streams. Event mean concentrations for PCB's and Bis(2-ethylhexyl)phthalate exceeded the standard more frequently than the other constituents. If chloride concentrations from earlier stormwater studies had been compared to the ground-water standard, the frequency of chloride exceeding the standard would have been greater. For example, higher maximum concentrations of chloride, $7,000 \mathrm{mg} / \mathrm{L}$, were observed in stormwater samples collected in 1977 from a freeway interchange in Milwaukee, Wis. (Bannerman and others, 1979).

Twenty-five constituents in storm sewer samples met the criteria for potential contaminants (table 9). Stormwater samples from urban streams had 16 constituents meeting the criteria. Many of the potential contaminants were found in both streams and storm sewers. These include metals, PAH's, DDT, Bis(2ethylhexy)phthalate, chloride, suspended solids, and fecal coliform. Potential contaminants exceeding the criteria for toxic substances can be grouped into five types of constituents-metals, PAH's, pesticides, phthalates, and PCB's. The five types of conventional constituents identified as potential contaminants include total phosphorus, suspended solids, fecal coliform, BOD 5-day, and chloride. With the identification of these 25 potential contaminants, Wisconsin stormwater management efforts could be directed toward BMP's which would target these contaminants.

\section{Bioassay Results}

Much concern has been raised about the validity of using current surface-water-quality criteria for toxic substances as a way of assessing the water-quality effects of stormwater on the receiving stream (Lee and Lee-Jones, 1993). A primary reason for this concern is that many of the constituents are not in a bioavailable form. The USEPA is considering changing the metals criteria such that they are based on dissolved concentrations and not total recoverable concentrations. Dissolved concentrations of zinc and copper in Wisconsin 
Table 9. Probability of event mean concentration of constituents in Wisconsin stormwater exceeding Wisconsin surface-water- and ground-water-quality standards $[--$, no value; $\mathrm{mL}$, milliliter]

\begin{tabular}{|c|c|c|}
\hline \multirow{2}{*}{ Constituent } & \multicolumn{2}{|c|}{ Probability of exceedance, in percen } \\
\hline & Storm sewers & Streams \\
\hline \multicolumn{3}{|c|}{ Acute toxicity criteria for coldwater fish communities $^{1}$} \\
\hline Cadmium, total recoverable & 11 & 0 \\
\hline Copper, total recoverable & 87 & 9 \\
\hline Lead, total recoverable & 18 & 0 \\
\hline Silver, total recoverable & 20 & -- \\
\hline Zinc, total recoverable & 91 & 7 \\
\hline \multicolumn{3}{|c|}{$\underline{\text { Human cancer criteria for public water supply/coldwater fish communities }}^{1}$} \\
\hline Benzo $[a]$ anthracene & 98 & 100 \\
\hline Benzo $[a]$ pyrene & 99 & 100 \\
\hline Benzo $[b]$ fluoranthene & 100 & 100 \\
\hline Benzo[ghi]perylene & 99 & 100 \\
\hline Benzo $[k]$ fluoranthene & 99 & 99 \\
\hline Chrysene & 100 & 100 \\
\hline Indeno pyrene & 100 & 99 \\
\hline Phenanthrene & 100 & 99 \\
\hline Pyrene & 100 & 100 \\
\hline DDT & 98 & 100 \\
\hline
\end{tabular}

Effluent limitations $^{2}$

$\begin{array}{lll}\text { Total phosphorus (Great Lakes) } & 9 & 0\end{array}$

Suspended solids (7-day average) $\quad 97 \quad 100$

BOD 5-day (7-day average)

50

Water-quality standards $^{3}$

Fecal coliform ( 400 counts $/ 100 \mathrm{~mL}) \quad 96$

99

Ground-water-quality standards: Enforcement standards ${ }^{4}$

Bis(2 ethylhexy)phthalate

60

44

Atrazine

2

0

Alachlor

2

0

2,4-D

2

0

PCB

42

0

Chloride

4

9

\footnotetext{
${ }^{1}$ Wisconsin Department of Natural Resources, 1989, chap. NR 105

${ }^{2}$ Wisconsin Department of Natural Resources, 1987, chap. NR 210

${ }^{3}$ Wisconsin Department of Natural Resources, 1989, chap. NR 102

${ }^{4}$ Wisconsin Department of Natural Resources, 1994, chap. NR 140
} 
storm-sewer samples also exceeded the acute toxicity criteria for metals.

The application of water-quality criteria to stormwater concentrations is questionable. Existing water-quality criteria were developed with reference to continuous point-source discharges. High flows in Wisconsin storm sewers usually last much less than 24 hours, and, on the average, rainfall occurs every 4 to 5 days. To overcome the limitations of using water-quality criteria to evaluate the effects of stormwater on a stream, investigators can use a multilayered monitoring approach (Pitt, 1991). This multilayered approach includes evaluating the habitat, water quality, sediment quality, biological community, and toxic responses of each stream.

Toxicological tests were used to enhance the comparison of water-quality criteria between the Urban Toxics Project and the Nonpoint Source Evaluation Monitoring Project. Acute bioassay tests were completed for 51 of the flow-composite samples collected from the Urban Toxics Project. In four of the samples, mortality of the zooplankton Ceriodaphnia dubia was almost 100 percent within 24 hours. This sample set consisted of one sample each from Monroe Street and Noyes Creek, and two samples from Wood Center. In one Wood Center sample, mortality of Daphnia magna was 75 percent. No effort was made to determine which constituents were responsible for the Daphnia magna mortality. None of the samples from any of the sites caused any significant mortality of fathead minnows. Even though metals concentrations exceeded the acute toxicity criteria, most of the samples did not cause significant mortality during the bioassays.

Preliminary results from in-place toxicological testing at the Lincoln Creek Nonpoint Source evaluation monitoring site indicates that the effects of stormwater are probably more chronic in nature (Kleist, 1995). Acute bioassay testing on Lincoln Creek during runoff events resulted in little short-term mortality of juvenile fathead minnows and Daphnia magna (Ramcheck and Crunkilton, 1995); however, the minnows began to die after 14 days of exposure to high- and lowflow water. By the end of the test, 60 to 90 percent mortality was observed for the test fish. After 14 days, 70 to 100 percent mortality was observed for Daphnia magna. About 10 more days of exposure was required to cause mortality in minnows exposed to low-flow water only. Long-term tests would be needed to qualify toxicological effects of stormwater.
Concentrations of one or more of the constituents in excess of water-quality criteria may have caused the toxicity to the test organisms. One potential source of these contaminants during low flow was the highly contaminated bottom sediments. Many of the potential contaminants in stormwater were found at high concentrations in bottom sediments (Masterson and Bannerman, 1994). Additional studies are being done at the Lincoln Creek Nonpoint Source evaluation monitoring site to determine the contribution of the bottom sediments to the toxicity of the base flow.

\section{Data Comparisons}

\section{Comparisons with Results from Other Areas}

Medians of event mean concentrations for seven constituents in stormwater from storm sewers were compiled from NURP and the NPDES data from the Dallas-Fort Worth, Texas area for comparison with the results from Wisconsin (table 10). All the monitoring efforts used similar sampling techniques. A substantial number of the medians were about the same. Nearly one-half of the NURP and NPDES medians were within 30 percent of the Wisconsin medians. Most of the remaining medians differed by less than 200 percent. The best agreement was seen for BOD 5-day, total phosphorus, and total recoverable zinc.

The largest difference was between NURP and Wisconsin lead concentrations; this difference is probably the result of lead removal from gasoline during the approximately 10 -year period between the NURP and Wisconsin studies. This hypothesis is supported by differences in event mean concentrations of heavy metals collected at Hastings Street and Wood Center between 1980 and 1990 . The median event mean concentrations of lead collected during NURP (in 1980) at Hastings Street and Wood Center were 50 and $450 \mu \mathrm{g} / \mathrm{L}$, respectively (Bannerman and others, 1983). Median event mean concentrations in samples collected about 9 years later at the same sites by the Urban Toxics Project were reduced to 13 and $112 \mu \mathrm{g} / \mathrm{L}$, respectively. No significant changes were seen, however, in the median event mean concentrations of zinc, copper, and suspended solids for the same sets of samples.

Similar concentrations of six pesticides were found in urban stormwater in Wisconsin and Minneapolis (Wotzka and others, 1994). Maximum event mean concentrations of dicamba, 2,4-D, alachlor, atrazine, 
Table 10. Comparison of event mean concentrations of selected constituents in Wisconsin storm-sewer samples with those in storm-sewer samples from other states

[BOD, biochemical oxygen demand; mg/L, milligrams per liter; $\mu \mathrm{g} / \mathrm{L}$, micrograms per liter; NURP, National Urban Runoff Project]

\begin{tabular}{|c|c|c|c|c|c|c|c|}
\hline \multirow[b]{2}{*}{ Location } & \multicolumn{7}{|c|}{ Medians of event mean concentrations } \\
\hline & $\begin{array}{c}\text { BOD } \\
\text { (mg/l) }\end{array}$ & $\begin{array}{c}\text { Suspended } \\
\text { solids } \\
\text { (mg/L) }\end{array}$ & $\begin{array}{c}\text { Phosphorus, } \\
\text { total } \\
\text { (mg/L) }\end{array}$ & $\begin{array}{l}\text { Orthophosphate, } \\
\text { dissolved } \\
\text { (mg/l) }\end{array}$ & $\begin{array}{c}\text { Copper, total } \\
\text { recoverable } \\
(\mu \mathrm{g} / \mathrm{L})\end{array}$ & $\begin{array}{c}\text { Zinc, total } \\
\text { recoverable } \\
(\mu g / L)\end{array}$ & $\begin{array}{c}\text { Lead, total } \\
\text { recoverable } \\
(\mu \mathrm{g} / \mathrm{L})\end{array}$ \\
\hline \multicolumn{8}{|c|}{ All sites } \\
\hline Texas $^{1}$ &.- & -- & -- & -- & -- & - & -- \\
\hline NURP $^{2}$ & 9 & 100 & 0.33 & 0.12 & 34 & 160 & 144 \\
\hline Wisconsin & 9.4 & 120 & .29 & .028 & 18 & 150 & 24 \\
\hline \multicolumn{8}{|c|}{ Residential } \\
\hline Texas & 7.3 & 78 & 0.33 & 0.21 & 8 & 60 & 13 \\
\hline NURP & 10 & 101 & .38 & .14 & 33 & 135 & 144 \\
\hline Wisconsin & $6^{3}$ & 47 & $.23^{3}$ & $.11^{3}$ & 7 & 50 & 10 \\
\hline \multicolumn{8}{|c|}{ Commercial } \\
\hline Texas & 6.6 & 52 & 0.14 & 0.06 & 8 & 80 & 30 \\
\hline NURP & 9.3 & 69 & .2 & .08 & 29 & 226 & 104 \\
\hline Wisconsin & 8.2 & 232 & .29 & .03 & 33 & 200 & 54 \\
\hline \multicolumn{8}{|c|}{ Industrial } \\
\hline Texas & 7.5 & 104 & 0.21 & 0.09 & 12 & 130 & 29 \\
\hline NURP & -- & -- & -- & -- & -- & -- & -- \\
\hline Wisconsin & 7.8 & 109 & .28 & .07 & 19 & 170 & 21 \\
\hline
\end{tabular}

cyanazine, and metolachlor were about the same in samples from the storm sewer draining into Lake Harriet in Minneapolis and from the four storm sewers monitored for pesticides in Wisconsin (table 7). Diazinon concentrations were determined for 26 sites during the NPDES monitoring in Texas. Median event mean concentrations for residential, commercial, and industrial sites in Texas were $0.55,0.10$, and $0.05 \mu \mathrm{g} / \mathrm{L}$, respectively. Because the median event mean concentration for Wisconsin was below the minimum reporting limit, only the mean value was available for comparison. The mean, $0.11 \mu \mathrm{g} / \mathrm{L}$, is in the range of the diazinon concentrations in Texas stormwater.

\section{Comparison of Storm Sewer and Urban Stream Concentrations}

A statistical comparison of storm sewer and stream event mean concentrations was done for eight potential contaminants: suspended solids, total phosphorus, total recoverable zinc, total recoverable lead, total recoverable copper, fecal coliform counts, benzo $[a]$ pyrene, and fluoranthene. A Wilcoxon ranksum test showed that differences between the stormsewer and stream concentrations were statistically significant for all the constituents except the PAH's. The relatively low number of concentrations available for PAH's might have made the statistical test insensitive to the differences between the stream and storm-sewer concentrations. PAH concentrations were compared using 30 values for storm sewers and 16 values for streams, while 247 suspended solids concentrations were available for storm sewers and 131 for streams.

These data are plotted in box plots (fig. 2). All the storm-sewer medians and means, except for fecal coliform counts, were slightly higher than those for the streams. Event mean concentrations of most constituents would be expected to be higher in stormwater from storm sewers, because of the dilution that can occur in a stream. Although differences in the concentrations were statistically significant, the magnitude of most of the medians was similar. For example, the median suspended-solids concentrations for storm sewers and streams were 120 and $107 \mathrm{mg} / \mathrm{L}$, respectively. Total 

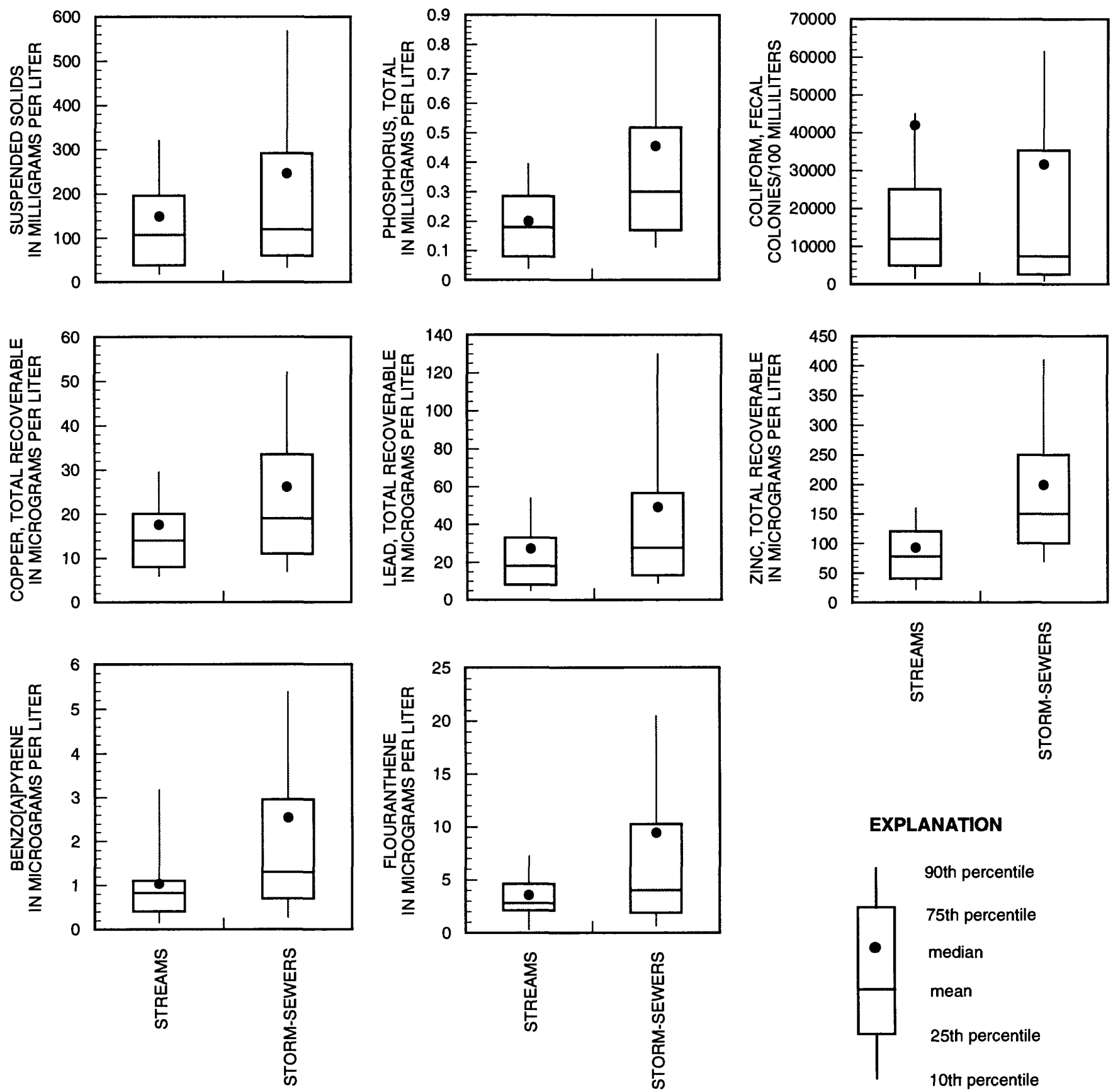

\section{EXPLANATION}

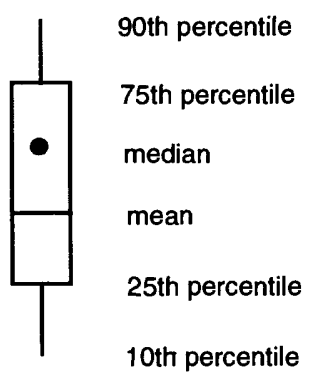

Figure 2. Differences in concentrations of selected constituents in storm-sewer discharge and urban streamwater in Wisconsin. 

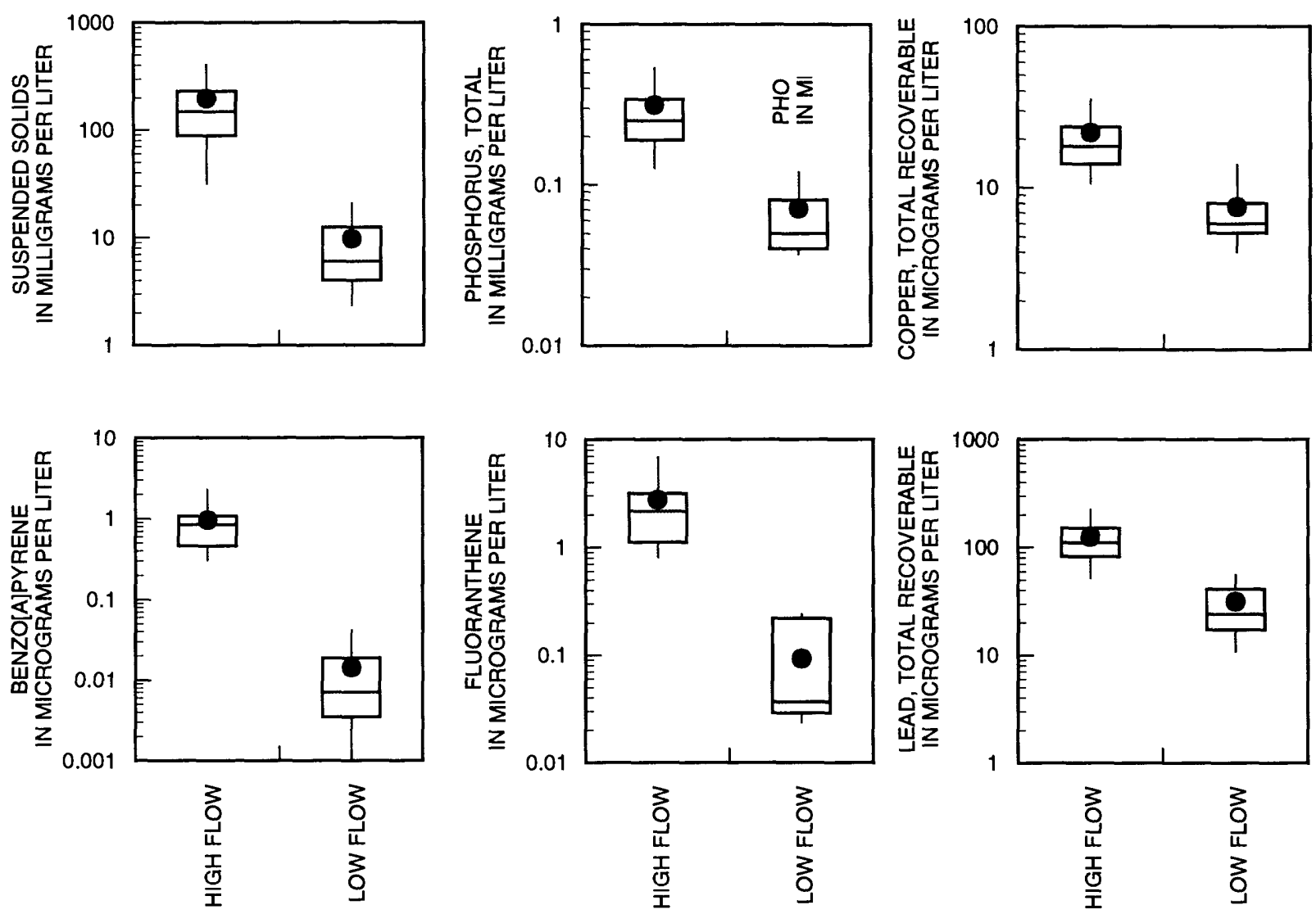

\section{EXPLANATION}

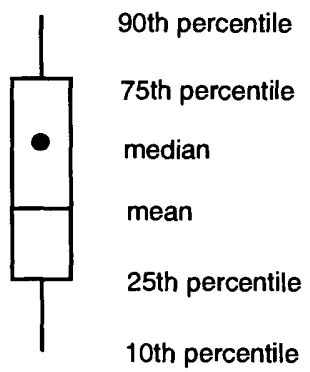

Figure 3. Boxplots of selected constituents during low-flow and high-flow periods at Lincoln Creek in Milwaukee, Wisconsin. 
recoverable zinc concentrations were farthest apart, with a median of $150 \mu \mathrm{g} / \mathrm{L}$ for the storm sewers and 77 $\mu \mathrm{g} / \mathrm{L}$ for the streams.

\section{Comparison of Stream Concentrations During Storms and Low-Flow Conditions}

Concentrations of six of the potential contaminants were much higher in Lincoln Creek during storm events than during low flow (fig. 3). Lincoln Creek is one of the urban streams monitored during the Nonpoint Source Evaluation Project. Low-flow samples were collected about every two weeks in Lincoln Creek. Stormwater concentrations for zinc and benzo $(a)$ pyrene were about 5 and 100 times greater than low-flow concentrations, respectively. A lack of overlap between distributions of concentrations in the box plots for high-flow and low-flow periods indicate that the differences are substantial. Stormwater substantially increases the concentration of potential contaminants in Lincoln Creek.

\section{SUMMARY AND CONCLUSIONS}

The U.S. Geological Survey, in cooperation with the Wisconsin Department of Natural Resources, has compiled a comprehensive data base of urban stormwater constituents. This is the most reliable data base available for Wisconsin stormwater between 1989 and 1994. This compilation lists the many types of constituents that were detected in at least 10 percent of Wisconsin stormwater samples as part of four urban waterquality studies performed in Wisconsin between 1989 and 1994. Almost any stormwater sample collected from Wisconsin storm sewers would be expected to contain some type of metal or PAH. Much of the time, these two types of constituents would probably be accompanied by one or more pesticides. Some agricultural herbicides would most likely be found along with the urban pesticides. Conventional constituents, such as suspended solids, would be found in all the samples. The high frequency of detection for these constituents indicates there are sources of these constituents in, or around, Wisconsin urban areas.

Water-quality standards cannot replace in-situ studies as an indicator of the effects of stormwater on receiving waters, but comparison of observed stormwater quality with water-quality standards is a useful interim approach to targeting the most likely constituents needing some control. Event mean concentrations of several types of constituents exceeded water-quality standards for Wisconsin surface and ground water. The 25 potential contaminants that exceeded water-quality standards are five metals (lead, zinc, copper, silver, and cadmium), nine PAH's, PCB's, Bis(2-ethylhexyl)phtha-late, bacteria, chlorides, BOD, suspended solids, total phosphorus, and four pesticides (alachlor, atrazine, 2,4-D, and DDT). This list of potential contaminants probably is not unique to Wisconsin. Studies in other states have found the same constituents with high detection frequencies and the event mean concentrations of some constituents exceeding water-quality standards.

Urban streams can be expected to reflect the quality of Wisconsin stormwater. Similarities in the types and levels of constituents found in storm sewers and urban streams indicate that many streams become little more than stormwater conveyance system during storm events. The degree of urbanization should influence both the quantity and quality of stormwater in urban streams. Concentrations of potential contaminants have shown a 100 fold increase during storm events for one urban stream.

More work needs to be done to describe the role of each potential contaminant in the quality of Wisconsin stormwater. Ongoing in-situ toxicological testing in Wisconsin will hopefully reveal more about the relative importance of selected metals and PAH's to the uses of an urban stream. More in-situ testing is also needed on lakes and ground water. Ground-water testing might focus on measuring in-situ concentrations and soil leaching rates of potentially toxic constituents, such as metals, PAH's, and pesticides. Although the impacts of the conventional constituents appear to be more obvious, especially for suspended solids, it could be helpful to know more about acceptable levels of these constituents in stormwater and their importance relative to the potentially toxic constituents.

\section{REFERENCES CITED}

Armstrong, D.E., and Llena, R., 1992, Stormwater infiltration potential for pollutant removal: Project Report, Wisconsin Department of Natural Resources, p. 10-18.

Arthur, J.W., Zischke, J.A., Allen, K.N., and Hermanutz, R.O., 1983, Effects of diazinon on macroinvertebrates and insect emergence in outdoor experimental channels: Aquatic Toxicology, v. 4, p. 283-301.

Bannerman, R.T., Owens, D.W., Dodds, R.B., and Hornewer, N.J., 1993, Sources of pollutants in Wiscon- 
sin stormwater: Water Science Techniques, v. 28, no. 3-5, p. 241-259.

Bannerman, R.T., Baun, Ken, Bohn, Michael, Hughes, P.E., and Graczyk, D.J., 1983, Evaluation of urban nonpoint source pollution management in Milwaukee County, Wisconsin: Chicago, Ill., U.S. Environmental Protection Agency, p. IV-1 to IV-37. [Available from National Technical Information Service as document PB 84114164.]

Bannerman, R.T., Konrad, J.G., Becker, D., Simsiman, G.V., Chesters, G., Goodrich-Mahoney, J., and Abrams, B., 1979, The IJC Menomonee River watershed study-Surface water monitoring data: Chicago, Ill., U.S. Environmental Protection Agency, Region V, Great Lakes National Program Office, EPA-905/4-79029-C, p. II-40.

Booth, D.B., Jackson, R.C., 1994, Urbanization of aquatic systems-degradation thresholds and the limits of mitigation-Proceedings effects of human-induced changes on hydrologic systems: American Water Resources Association, p. 425-434.

Brush, S.W., Jennings, M.E., Young, J.P., and McWreath, H.C., 1994, NPDES monitoring-Dallas-Fort Worth, Texas area: Proceedings of an Engineering Foundation Conference, Stormwater NPDES Related Monitoring Needs, p. 115-143.

City of Madison [Wisconsin], 1994, Report on road salt reduction program and study 1994: Madison, Wis., Department of Public Health, 5 p.

Cooke, T., Drury, D., Katznelson, R., Lee, C., Mangarella, P., and Whitman, K., 1994, Storm water NPDES monitoring in Santa Clara Valley: Proceedings of an Engineering Foundation Conference, Stormwater NPDES Related Monitoring Needs, p. 144-177.

Corsi, S.R., Walker, J.F., Graczyk, D.J., Greb, S.R., Owens, D.W., and Rappold, K.F., 1995, Evaluation of nonpointsource contamination, Wisconsin-Selected streamwater-quality data, land-use and best-management practices inventory, and quality assurance and quality control, water year 1993: U.S. Geological Survey Open-File Report 94-707, 57 p.

Federal Highway Administration, 1984, Sources and migration of highway runoff pollutants: Volume III, FHWARD-841059, p. 4-15.

1990, Pollutant loadings and impacts from highway stormwater runoff: Volume III, FHWA-RD-88-008, p. 9-12.

Field, R. and Pitt, R., 1990, Urban storm-induced discharge impacts-U.S. Environmental Protection Agency research program review: Water Science Technology (G.B.), v. 22, no. 10-11, p. 1-7.

Fram, S., Stenstrom, M.K., and Silverman, G., 1987, Hydrocarbons in urban runoff: Journal of Environmental Engineering, v. 107, p. 1032-1046.
Gustav, R.S., Sovern, D.T., and Washington, P.M., 1994, Maintaining fish habitat in urban streams: Water Environment and Technology, p. 48-53.

Hansen, J., Sesing, M., Hughes, P.E., and Graczyk, D.J., 1983, Evaluation of urban nonpoint source pollution management in Milwaukee County, Wisconsin: PB 84114180, Volume III, U.S. Environmental Protection Agency, Chicago, Ill., p. II-1-II-26.

Helsel, D.R., and Hirsch, R.M., 1995, Statistical methods in water resources: Amsterdam, Elsevier Science Publishers, p. 357-364.

Horner, R.R., Skupien J.J., Livingston, E.H., and Shaver, E.H., 1994, Fundamentals of urban runoff management-Technical and institutional issues: Terrene Institute, p. 43-56.

Jones, R.F., 1991, Once again the fire lights in my heart: Sports Illustrated, July 15.

Kleist, J., 1995, Draft final report, toxicological effects of stormwater runoff in Lincoln Creek, Milwaukee, Wisconsin: Madison, Wis., Wisconsin Department of Natural Resources, $5 \mathrm{p}$.

Kroupa and Associates, 1995, Westmorland Lawn Care survey: Prepared for City of Madison, Wisconsin, Department of Public Works Engineering Division.

Lee, G.F., and Lee-Jones, A., 1993, Water quality impacts of stormwater-associated contaminants-Focus on the real problems: Water Science Technology, v. 28, no. 3-5, p. 231-240.

Lee, G.F., and Lee-Jones, A., 1994, Stormwater runoff management-Quality problems being addressed by current structural best management practices: Public Works, p. 53-55; p. 71-72.

Lin, M., Capel, P.D., and Wotzka, P.J., 1994, Pesticides in rain in Minnesota: Minnesota Department of Agriculture.

Masterson, J.P., and Bannerman, R.T., 1994, Impacts of stormwater runoff on urban streams in Milwaukee County, Wisconsin: Proceedings National Symposium on Water Quality, American Water Resources Association, p. 123-133.

National Research Council of Canada, 1983, Polycyclic aromatic hydrocarbons in the Asiatic environment-Formation, sources, fate, and effects on aquatic biota: Pub. No. NRCC 18981 of the Environmental Secretariat.

Pitt, R. (1991) Biological impacts associated with urban runoff in effects of urban runoff on receiving systems: an interdisciplinary analysis of impact, monitoring, and management, Engineering Foundation Conference, Mt. Crested Butte, Col., ASCE N.Y.

Pitt, R., 1994, Small storm hydrology—handout at Designing stormwater-quality management practices course: Madison, Wis., University of Wisconsin-Extension, May 17-19, 1994. 
Pitt, R., Field, R., Lalor, M., and Brown, M., 1995, Urban stormwater toxic pollutants-Assessment, sources, and treatability: Water Environment Research, v. 67, no. 3, p. 260-275.

Ramcheck, J., and Cunkilton, R., 1995, Toxicological evaluation of urban stormwater runoff in Lincoln Creek, Milwaukee, Wisconsin: Madison, Wis., Wisconsin Department of Natural Resources, $77 \mathrm{p}$.

Schueler, T., 1994, The importance of imperviousness: Watershed Protection Techniques, v. 1, no. 3, p. 100 111.

Simonson, T., and Lyons, J., 1993, Evaluation monitoring of fish and habitat during priority watershed projectsProgress report for evaluation monitoring program: Wisconsin Department of Natural Resources Bureau of Research, p. 5-11.

Thomas, M.P., and McClelland, S.I., 1994, NPDES monitoring-Atlanta, Georgia Region: Proceedings of an Engineering Foundation Conference, Stormwater NPDES Related Monitoring Needs, p. 95-114.

U.S. Environmental Protection Agency, Water Planning Division, 1983, Results of the nationwide urban runoff program: Washington, D.C., p. 6-1-6-64. [Available from National Technical Information Service as document PB 84-185552.]

Wang, Lizhu, Lyons, J.D., and Kanehl, P.D., 1995, Evaluation of the Wisconsin Priority Watershed Program for improving stream habitat and fish communities:

Monona Wis., Wisconsin Department of Natural Resources, Fish Research Section, 124 p.

Wisconsin Department of Natural Resources, 1992, Groundwater quality: Wisconsin Administrative Code 433, chap. NR140.

Wisconsin Department of Natural Resources, 1989a, Surface water quality criteria for toxic substances: Wisconsin Administrative Code 398, chap. NR105.

Wisconsin Department of Natural Resources, 1989b, Water quality standards for Wisconsin surface waters: Administrative Code 398, chap. NR102.

Wisconsin Department of Natural Resources, 1987, Sewage treatment works: Administrative Code 374, chap. NR210.

Wotzka, P.J., Lee, J., Capel, P., and Lin, M., 1994, Pesticide concentrations and fluxes in an urban watershed: National Symposium on Water Quality, Proceedings American Water Resources Association, p. 135-145. 